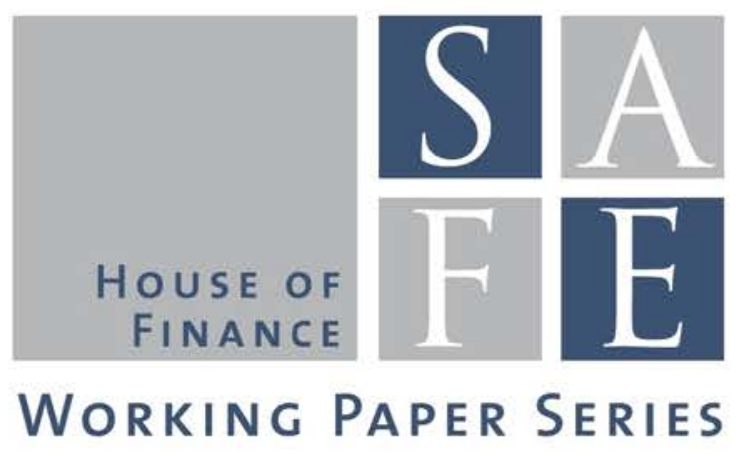

Edin Ibrocevic - Matthias Thiemann

\title{
All Economic Ideas are Equal, but Some are more Equal than Others: A Differentiated Perspective on Macroprudential Ideas and their Implementation
}

SAFE Working Paper No. 214

SAFE I Sustainable Architecture for Finance in Europe A cooperation of the Center for Financial Studies and Goethe University Frankfurt 


\section{Non-Technical Summary}

The shift from a microprudential regulatory framework, where the safety and stability of individual financial institutions was the key focus, towards a macroprudential framework, in which the financial system as a whole is the focus of regulatory efforts, has been sudden and unexpected after the great financial crises of 2007-08. The macroprudential approach promised a top-down regulatory set up, with a special focus on anti-cyclical regulation. Yet, 10 years after the crises, anti-cyclical regulations have been few and far apart on the international level (with the sole exception of counter-cyclical capital buffers). Rather, new regulations focused mainly on increasing the resilience of the system via regulations of too big to fail banks and their potential negative externalities (recovery and resolution regimes, core capital for G-SIFI, TLAC and MREL). Further regulations tackled issues of contagion and interconnectedness (CCPs or Net Stable Funding Ratio), but little to none the cyclical build-up of systemic risk over time. This paper seeks to better understand this gap between the new regulations implemented post-crises and the original macroprudential framework outlined by Claudio Borio in the early 2000s, which strongly embraced such counter-cyclical interventions.

To do so, it adopts Carstensen's (2011) framework analyzing the ideational impact on regulations that conceptualizes policy makers as bricoleurs, who interact with ideas in a strategic and practical fashion. Based on insights of regulatory science and recent studies on the scientification of central banks, Carstensen argues that policy makers require the backing of norm-free scientific discourse as a resource in epistemic battles over new financial regulation. Using this concept, this paper investigates the scientific legitimacy bestowed upon these different interventions pre- and postcrisis. To analyze the standing of these different ideas in the scientific discourse this paper gathered a new dataset consisting of over 4000 documents on the topic of systemic risk and macroprudential regulation and used advanced quantitative text analysis to track when certain ideas were available to which actors in the discourse of financial economics post-crises. The analysis reveals that indeed only ideas with backing of academia were able to be implemented into regulation (almost all of which focus on increasing the resilience of the financial system). Furthermore, the analysis provides evidence that it is not new systemic risk thinking per se that academics avoid engaging with. Rather, it is the time-variant analysis of new systemic risk thinking and that is problematic for academia. This fact, besides institutional and political opposition to anti-cyclical intervention, was one problem which narrowed the ideas used for new regulations.

Our analysis indicates two problems for future policy making. Firstly, albeit some very prominent exceptions, there seems to be little indication of mainstream academia properly engaging with the topic of the financial cycle. Considering the demand for scientific backing of economic ideas for regulation, this epistemic divide between policy makers in central banks and international organizations and academia acts as a barrier for cyclical ideas to being taken more seriously in policy debates. A second, longer term implication for policy makers is subtler. If policy makers want to bring the unique problems on financial cycles they face to the forefront, they must grapple with the question of what kind of requirements their knowledge must meet to become viable for new regulation. Is in-house knowledge production by central banks sufficient to generate legitimate knowledge? How should researchers in research units of central banks relate to academics? Which are the forms of interaction between academia and central banks that could foster the production of scientifically backed and accepted knowledge on the financial cycle? Our results portray a developing collaboration between central bankers and academics, on which further research is needed. 


\title{
All economic ideas are equal, but some are more equal than others: A differentiated perspective on macroprudential ideas and their implementation
}

\author{
Edin Ibrocevic - Goethe University Frankfurt, Germany \\ Sociology Department \\ Matthias Thiemann, PhD - Sciences Po Paris ${ }^{1}$ \\ Centre d'Etudes Europeens
}

\begin{abstract}
In this study we investigate which economic ideas were prevalent in the macroprudential discourse post-crises in order to understand the availability of ideas for reform minded agents. We base our analysis on new findings in the field of ideational shifts and regulatory science, which posit that change-agents engage with new ideas pragmatically and strategically in their effort to have their economic ideas institutionalized. We argue that in these epistemic battles over new regulation, scientific backing by academia is the key resource determining the outcome. We show that the present reforms implemented internationally follow this pattern. In our analysis we contrast the entire discourse on systemic risk and macroprudential regulation with Borio's initial 2003 proposal for a macroprudential framework. We find that mostly cross-sectional measures targeted towards increasing the resilience of the financial system rather than inter-temporal measures dampening the financial cycle have been implemented. We provide evidence for the lacking support of new macroprudential thinking within academia and argue that this is partially responsible for the lack of anti-cyclical macroprudential regulation. Most worryingly, the financial cycle is largely absent in the academic discourse and is only tacitly assumed instead of fully fledged out in technocratic discourses, pointing to the possibility that no anti-cyclical measures will be forthcoming.
\end{abstract}

${ }^{1}$ Corresponding author: matthias.thiemann@sciencespo.fr. We would like to thank SAFE at the House of Finance in Frankfurt for the financing of this study. 


\section{Introduction- An overview of post-crises regulatory changes}

The rise of macroprudential thinking to the heights of regulatory rule-making after the crisis of 20072009 was as sudden as it was unexpected. Having largely developed outside of, and often in direct opposition to mainstream academic thinking, macroprudential regulation was to be the regulatory answer to the glaring regulatory shortcomings revealed by the crisis. ${ }^{2}$ Rather than focusing on individual institutions, it was to install a system wide top down perspective that sought to limit the chain reactions and feedback loops which had brought the financial system to a standstill in 2008. Macroprudential thinking was to be transferred from broad based proposals into concrete regulatory tools, pursuing the two goals macroprudential regulation had set out for itself: raising the resilience of the financial system as well as reducing its cyclical character (Crockett 2000).

Much has been written regarding the regulatory reform activities of the last decade, both on the level of the G20 (Duffie 2016, FSB 2017) as well as on the European level (ESRB 2014). In broad strokes, one can argue that the initiatives labeled as macroprudential broadly tackle the resilience of the system but leave the cyclical character largely untouched (Tucker 2016, Thiemann et al 2018). Measures that seek to tackle too big to fail banks and their potential for negative externalities (recovery and resolution, Core capital for G-SIFI, TLAC and MREL) have been prominent throughout the process. Furthermore, measures that seek to reduce interconnectedness and contagion in the financial system, in particular with respect to derivatives through the mandatory clearing of standard derivatives through CCPs have been seen as necessary and impactful (Tucker 2014, 3), as has been the Net Stable Funding Ratio (NSFR) that purposefully limited the intermediating capability of broker dealers in the repo market (Tarullo 2014, critical Duffie 2016). On the other hand, measures that seek to directly limit the cyclical character of the financial system, be it in central financial markets, such as the repo market, be it in the banking system have largely not been forthcoming (Edge and Liang 2017, 3 Thiemann et al 2018). Even the counter-cyclical capital buffer, the poster-child of macroprudential reforms primarily seeks to increase the resilience of the system, rather than operating as an anti-cyclical intervention.

What can explain this selectivity and one-sidedness of reform measures? Is it the reflexive restraint of technocrats fearing over-reach that would threaten the independence of their agencies (Tucker

\footnotetext{
2 The term "macroprudential" has been around since 1979 (Maes 2009) but the framework as it is understood today was properly developed in the early 2000s (Baker 2013a: 114).

${ }^{3}$ In a large survey of the macroprudential frameworks of 54 countries, Edge and Liang conclude that only 2 countries have a fully operational anti-cyclical apparatus.
} 
2016)? Is it the difficulty of pushing through new macroprudential measures against the resistance of private interests (Underhill 2015) or the resistance of critical microprudential regulators (Baker 2014, Moschella and Tsingou 2013), who largely resist the claims for new turf for their macroprudential colleagues within regulatory agencies? This paper will take a related but different route. It will suggest that it is the selective backing of regulatory measures by the academic mainstream before and during the financial crisis that has had a large effect on the measures pursued by regulators; those topics where academics and regulators agreed were pursued in terms of the creation of regulatory measures, whereas those pushed solely by regulators and economists within regulatory agencies were largely ignored.

A first valuable insight pointing in this direction comes from a seminal text by Claudio Borio from 2003, in which he sought to define the macroprudential reform agenda. In it, he distinguished his new vision of systemic risk from the old, established systemic risk thinking, prevalent in mainstream academia at the time. Old systemic risk thinking, which was mostly cross-sectional and had only a very limited inter-temporal dimension focused on the impact of exogenous shocks on the system and its reverberations. This static conception led to a focus on the resilience of individual firms to withstand short-term shocks and a willingness to reduce second round effects by limiting interconnectedness and contagion (Borio 2003, 5). In contrast, new systemic risk thinking perceives systemic risk to be endogenous to the financial system, building up over the cycle through the "common exposures to macroeconomic risk factors across institutions" (Borio 2003: 6) which in and of themselves are co-produced by the financial system. Looking at the measures enumerated above, it is remarkable that almost all of the measures implemented on the level of the G20 as well as the European level can be grouped into the old systemic risk thinking that Borio sought to overcome.

To make this point, this paper proceeds as follows: it first outlines post crisis financial regulatory changes. We mainly focus on regulatory changes on the international level using either existing literature on the topic or interview data. Furthermore, some comparative studies of macroprudential institutional set ups are used to show what type of regulation was implemented post financial crises. Afterwards we present some general results of our topic modelling and continue with a more detailed analysis of topics related to the identified regulatory changes.

\section{The regulatory changes post-crisis}

In figure 1 below, we graphically represent the macroprudential measures emanating from Basel III and implemented up until 2014 in Europe and at the global level. 


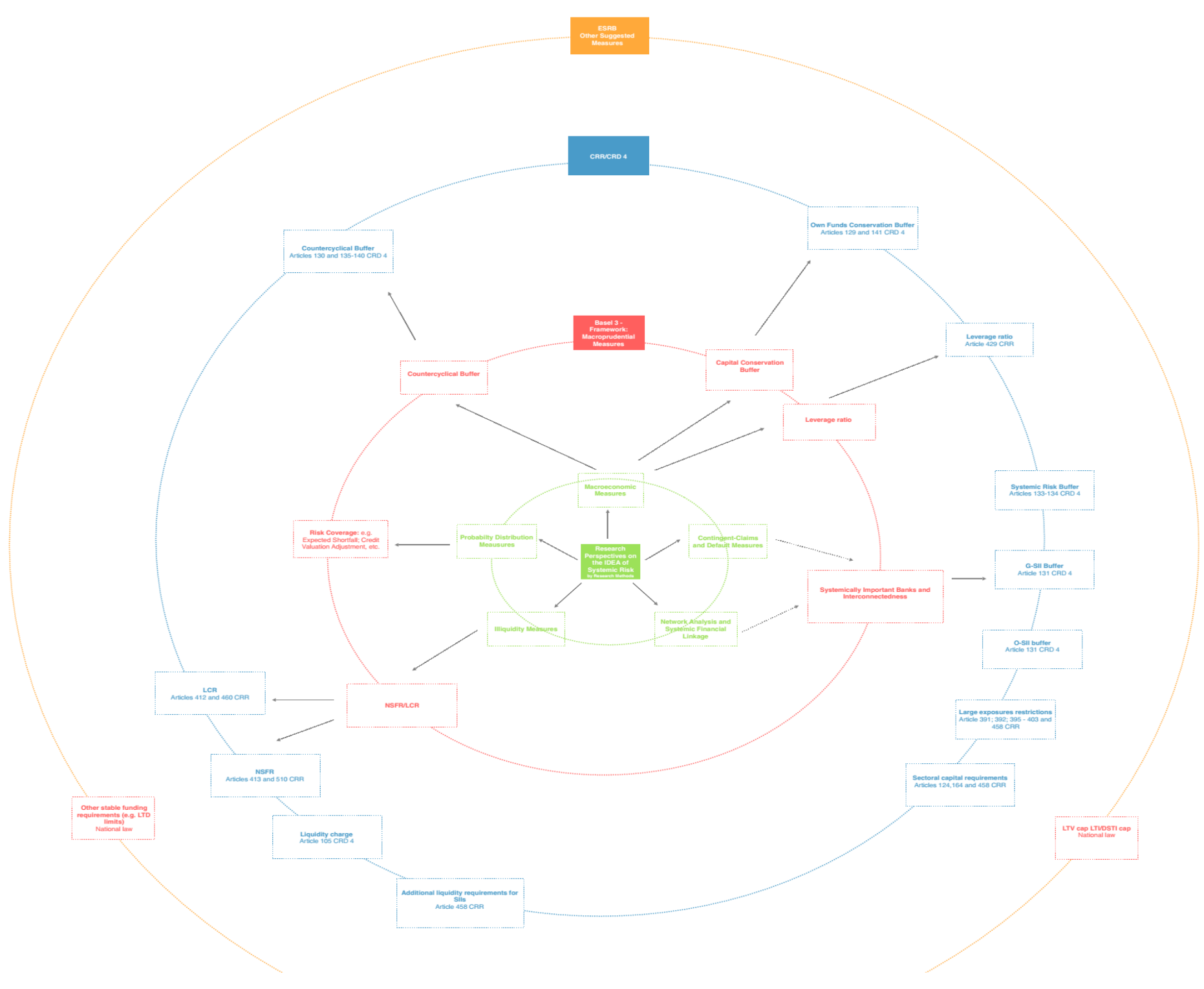


The one major reform missing in the graph above is the one of OTC derivatives through mandatory clearing through CCPs needs to be added as a major global reform, an idea first voiced at the G20 in Pittsburgh in 2009 and transformed into policy in Europe through EMIR by 2012 (Thiemann et al 2018). This reform was driven by the concern over interconnectedness and the relatively robust performance of CCPs. What is remarkable about the reforms above is that none of them has a clear anti-cyclical purpose. Even the CСyB, often seen as the poster child of macroprudential tools (Baker 2013) is directly addressing issues of resilience, its anti-cyclical impact a potential add-on to its primary aim of strengthening resilience (BCBS 2018, https://www.bis.org/bcbs/ccyb/). Edge and Liang find similar results on the national level (2017). Analysing 54 financial stability frameworks around the world, Edge and Liang find only 18 of them to have anti-cyclical policies at all, and only 2 of them (France and UK) to be set up in a way that favors action (ibid).

Comparing the above, which distinguishes in the core the underlying measures from the policy tools finally implemented with the report on potential systemic risk measures published by the Office for Financial Research in January 2012 shows the selectivity of the measures finally implemented. The figure below displays an overview of ways to measure systemic risks and possible tools to implement, showing the surplus of ideas over those being finally implemented (s. figure 2 below, s. also Bisias et al 2012, mentioning 34 possible systemic risk measures). Whereas the possible tools displayed are less numerous in graph 2 than in the graphic above, this is due to the different focus of the report, which rather than investigating potential tools primarily sought to display ways to measure systemic risk. 


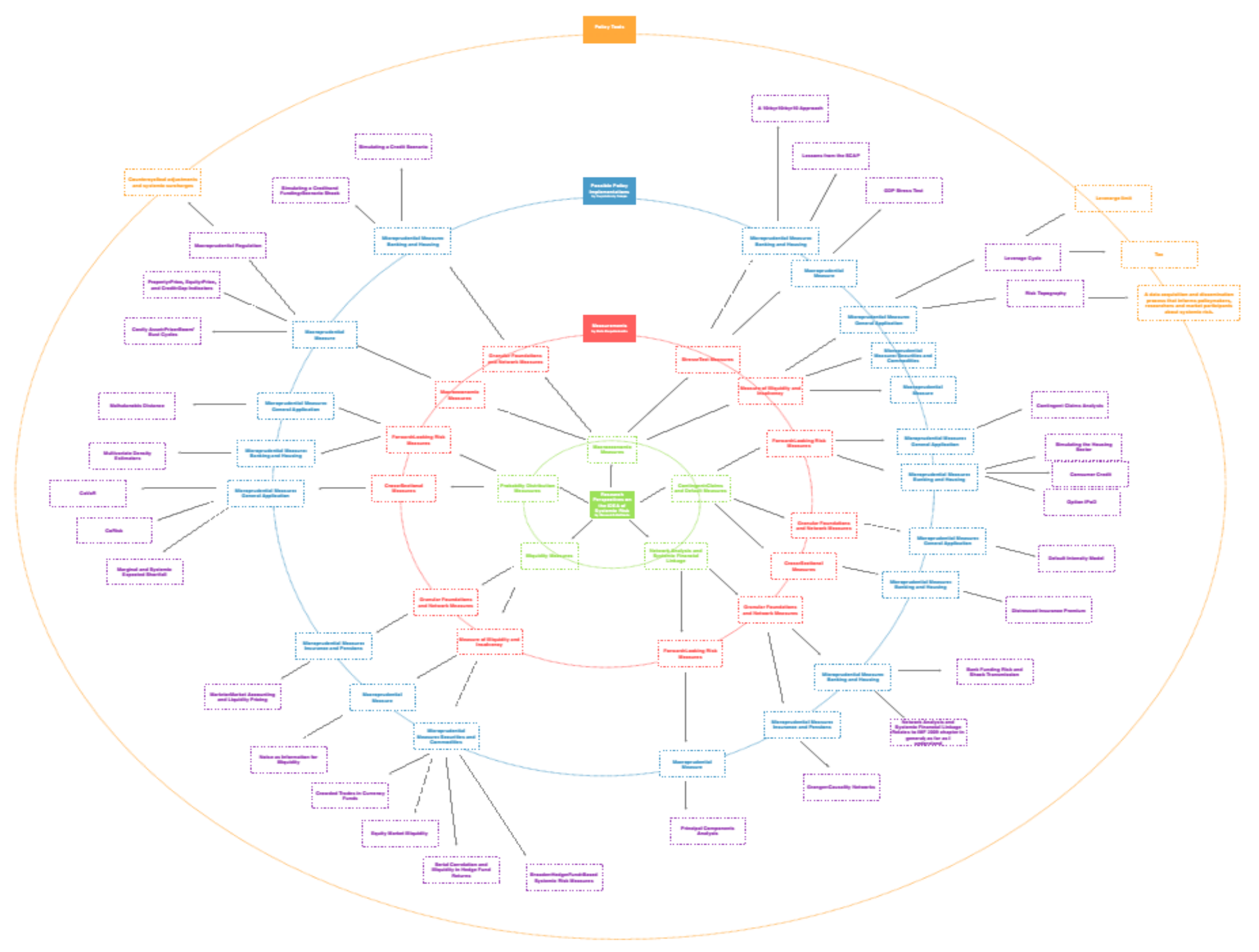


How can this selectivity of ideas and measures which were finally implemented be explained? In this study we will not focus on what happens to ideas once they go through institutional processes and are transformed into regulation. Rather, we try to provide a framework to analyze which ideas are more likely to be considered as potential candidates for this process in the first place. To do so, we analyze which ideas are discussed when in various parts of the economics discourse on systemic risk and macroprudential regulation. We therefore conduct a quantitative content analysis on a sample of the entire macroprudential and systemic risk discourse, seeking to understand the way policy makers in central banks interacted with academic economists in the construction of the macroprudential regulatory reform agenda. The next two sections will review the literature and review our theoretical approach before we introduce our dataset and the method of analysis we employ, then to present our results.

\section{Literature review}

The literature on post crises regulatory changes is somewhat paradoxical. On the one hand work by Andrew Baker (2013a, 2013b) seems to indicate, that a complete ideational shift within the technocratic community towards macroprudential regulation has occurred. On the other hand other studies have shown, that new regulations have not come to fruition yet (Underhill 2015, Helleiner 2014, Mügge 2013). The paradox seems to stem from a lack of a holistic analysis of the post crisis ideational shift and subsequent regulatory changes. Most studies either provide a detailed explanation for a particular set of regulations or are case studies of national regulatory changes (Mero and Piroska 2017, Yagci 2017). The problem with the above studies is that they all focus on successful regulatory changes. This does not allow for a proper analysis of causal mechanisms, due to the lack of variance in the outcome (Pagliari and Wilf 2018). In this section, we will review some of the most important studies on the ideational shift towards macroprudential regulation and will argue that the shortcomings of these study are partially responsible for the apparent paradox in the literature.

Andrew Bakers (2013a) initial study on the ideational shift from micro- to macroprudential regulation indicates that a rapid ideational shift has occurred after the financial crises. During this time the macroprudential shift was, according to Baker (2013a), mainly advanced by a small group of economists surrounding Claudio Borio and William White at the BIS. These economists acted as change agents and managed to persuade other economists, mainly in central banks and other international organizations of the macroprudential idea and position themselves in key policy 
making positions in the post crises regulatory process, from which they were able to influence policy processes and further convince other economists, creating a rapid ideational shift, a "technocratic coup d'etat", in which the previous microprudential paradigm was replaced.

Although, the ideational shift was rapid and largely successful a multitude of impediments prohibited macroprudential ideas to be fully translated into regulation (Blyth 2013, Baker 2013b, Moschella and Tsingou 2013, Baker 2015, Underhill 2015, Moschella and Lombardi 2017). The stifled implementation of macroprudential regulation, however, calls into question the account given by Baker (2013a). For example, if the ideational shift was as all-encompassing as Baker describes and if ideas are used to form new institutions as argued by Blyth (2002), then how come the most central macroprudential idea, the financial cycle, has yet to be translated into meaningful anti-cyclical regulation? (Thiemann et al forthcoming, Thiemann forthcoming)

Much of the shortcomings of Bakers study can be found in two main issues: his conceptualization of actors and ideas. For Baker actors can either be entirely convinced of the new paradigm or not convinced at all; they have no way to select ideas or interact with them to their benefit. Bakers actors seem to be forced to accept all parts of the MPR idea. The complete acceptance of all parts of the macroprudential idea without any struggle, contemplation or contestation on the part of the actors seems highly unlikely and is not backed by the empirical data (Thiemann et al 2018). Furthermore, all types of economists (central bankers/academics etc.) seem to be equally convinced of ideas no matter their institutional set up. Again, work on economic framing and various cultures within the economic profession indicate, that this is an unlikely case (Reay 2015, Fourcade 2009).

More important than the seemingly homogenous acceptance of all macroprudential ideas by actors, is Bakers assumption that all macroprudential ideas are equally likely to be accepted by all types of economists. Here, the fact that macroprudential thinking developed outside of the mainstream and actually in partial contradiction to main tenets of that mainstream, is especially important (s. the pre-crisis literature on rational bubbles, s. also Thiemann et al 2017). Given the partially orthogonal opposition of macroprudential thinking to the paradigm of rational agents-based macro-economics, emblematically embedded in DSGE models and the Lucas critique which underlies it, one is left to wonder whether Baker is not employing an overly optimistic model of paradigmatic change, which underestimates the investment of leading academic economists in their models.

Furthermore, research on regulatory science indicates that, depending on which regulatory culture is encountering ideas, not all economic ideas are perceived as equally valid(Hall 1989, Jasanoff 2008). 
Following work by Sheila Jasanoff (2011) a key component for policy making is the objectivity of the knowledge on which policies are based on. Jasanoffs main conclusion is that different regulatory cultures have distinct ways of producing objectivity. The perceived objectivity of ideas is an important resource in the epistemic battle over ideas, since it allows the policy maker to base the intervention into the economy on norm-free objective knowledge and thereby insulate himself from blame (Hood 2009, Jasanoff 2011). In the case of the ideational shift towards macroprudential regulation, the differing social construction of objectivity, puts varying requirements on macroprudential ideas. Hence, some parts of the macroprudential concepts might be accepted as objective and thus as legitimate in some institutional contexts, but not in others. The role of academic economists' expertise in providing legitimation for these new measures can be crucial and their endorsement in no way is unequivocally positive regarding the new macroprudential world-view.

Both, the conceptualization of actors and of ideas, have been underdeveloped in the analysis of the ideational shift towards macroprudential regulation. In addition to that, previous studies have only focused on macroprudential ideas as a monolithic idea set instead of dealing with macroprudential ideas as a more heterogeneous set of ideas. These factors are largely responsible for the perceived paradox in the study of ideational shifts. On the one hand the ideational shift seems to have been successful and some macroprudential regulations have been implemented. On the other hand, no major shifts within the regulatory set up towards macroprudential regulation have occurred. To clear up this confusion, we will introduce the concept of the bricoleur (Carstensens 2011), who is capable of interacting strategically with ideas and further theorize on why certain ideas could become more important than others.

\section{Theory}

More recent developments in research on ideational shifts has pointed out, that the focus of the ideational literature on exogenous shocks, which cause actors to adopt new ideas and then compete for having them institutionalized, does not take into account the strategic and pragmatic interactions of actors with ideas (Carstensens 2011). To remedy this shortcoming Carstensens (2011) introduces the concept of the bricoleur, who is capable of interacting pragmatically with ideas. Once a new problem emerges the bricoleur is capable of choosing and picking ideas, based on previous practices, knowledge and more importantly the surrounding institutional interests the bricoleur is embedded in. By combining ideas the bricoleur as a political actor is able to use ideas creatively in modelling his world and in strategic epistemic battles. This view brackets the question whether the bricoleur is convinced or not by the ideas employed, and rather focuses on his ability to engage and translate 
ideas to fit into the current political situation, providing the bricoleur with the ability to further his goal to the fullest extent. For the study of macroprudential ideational shifts the bricoleur is a useful concept, since it allows actors to choose parts of the macroprudential ideas based on their chances of success in his contested epistemological field.

Although, the bricoleur is capable of choosing and picking ideas in a strategic manner, it is still unclear what the requirements for the successful acceptance of ideas are. Very few studies have actually focused on what kind of requirements ideas must fulfill to become accepted (Hall 1989, Wigger and Buch-Hansen 2014). We adopt the theoretical framework outlined by Peter Hall and contributors in their analysis of the shift towards Keynesianism after the Great Depression. Peter Hall (1989) differentiates between three different institutional constrains for economic concepts to be considered by actors. Economic viability, refers to ideas "apparent capacity to resolve a relevant set of economic problems" (Hall 1989, p. 371) and how the ideas in question relate to previous economic theory, the current state of the economy and international constrains. The administrative viability of ideas is given, if the idea is "accorded with the long-standing administrative biases of the officials responsible for approving it and seemed feasible in light of the existing implementation capacities of the state" (Hall 1989, p. 373). For an idea to become politically viable, it has to concur with the overall goals of the ruling political parties allow for potential coalitions in the wider political sphere and has to be able to connect to other policy proposals. Hence, macroprudential ideas would be examined based on their validity, the assertion being that the more they adhere to the three validities the more likely they are to become implemented as policies.

New economic ideas are required to have all three validities to become viable, but Hall rightly points out that economic ideas are not required to have all of them to the same degree. Often some economic ideas have high economic validity while lacking political backing or the state lacks the administrative capacity for implementation. Either way, a lack in one validity can be substituted with more validity in the other two. Even though validities are somewhat interchangeable, the question of how validities are ranked is still open for debate. Here, institutional consideration and the actual economic problem at hand come into play. Studies conducted on the development of central bank discourse have shown, that central banks have undergone a process of scientization in the past 20-30 years (Marcussen 2009, Krippner 2011). Furthermore, studies conducted on the question of when economics actually influences policy making, show that the case of financial regulation and macroprudential policy meet the requirements of a policy field in which economics itself has a large influence on policy making (Hirschman and Berman 2014, Wigger and Buch-Hansen 2014). 
Given the scientization of central banking and a policy field that is conducive to economics as the base for policy making, economic validity seems to be a necessary condition to be met by macroprudential regulation. Epistemic backing by economics is a key factor for economic ideas to become viable for regulation, but so far we have only discussed that it is important, but not why. The field of regulatory science (Jasanoff 2011) provides us with insights in how objectivity is used in regulation, since it "partakes of the neutrality and impartiality of science itself, and demonstrations of objectivity can insulate the claimant against charges of arbitrariness or self-interest" (Jasanoff 2011, p. 2), In short, the deference to scientific knowledge via objectivity in regulatory processes, provides regulators with a way to insulate themselves from claims of arbitrariness, value-laden decisions and blame (Jasanoff 2011, Hood 2009, Krippner 2011). Jasanoff also points out that objectivity is resource with which epistemic claims can be supported, but at the same time objectivity is "culturally situated, contested, and enacted at multiple sites and organizational level" (Jasanoff 2011, p.2).

The social construction of objectivity necessary for regulatory action to justify the large scale interventions required by the macroprudential agenda, the context of scientifically oriented central banks and the larger context of financial regulators leads to the conclusion that economic validity as outlined above, is the most important type of validity, that is to say which ideas are even selected at the beginning of a regulatory process 4 . Yet, as described above the bricoleur is not only interested in actively solving the pragmatic problem at hand, but also in which ideas can be employed in his current political and administrative circumstances. Thus, in the case of macroprudential regulation the bricoleur finds himself at the border between scientific knowledge produced by economics and the institutional set up he is embedded in. Any economic idea, which could be considered by the bricoleur, has to be able to gain traction in both realms, a process that is often called epistemic boundary work (Gieryn 1995, Gieryn 1983, Jasanoff 1987, 1990). This means, that for the bricoleur to engage with these ideas in his policy-field, ideas must be translatable into his policy field from economics (Callon 1984). To be more precise, every economic idea has to establish scientific objects, which model the economy in such a fashion, to allow the policy maker to legitimately and effectively intervene into the economy based on the political and administrative options available to the bricoleur (Breslau and Yonay 1999), while at the same time insulating him from blame. These scientific objects are what bridge the border between scientific/unscientific knowledge and the

\footnotetext{
${ }^{4}$ Accordingly, our research found a heavy engagement of regulatory agents considering the regulation of the financial cycle with the academic research undertaken to specify the phenomenon, its amplitude and nature (s. Thiemann et al 2018)
} 
border between scientific knowledge and knowledge used for policy makers in an era of evidencebased public policy (Strassheim 2015, Quack 2016).

This is not to say, that only ideas backed by economics as a science are potential candidates for regulation, rather ideas with high economic validity via scientific backing have a higher probability of being used. The bricoleur can wield economically valid ideas in epistemic battles within his institutional and political setting (Blyth 2013). During these epistemic battles, the bricoleur pragmatically employs economic ideas backed by academia to further his interests and position. ${ }^{5}$ To understand the difficulties such bricoleurs faced as they strived for a viable macroprudential framework, we will now shortly outline the epistemic challenge macroprudential thinking in the 2000s posed to the academic mainstream, then to analyze the evolution of the discourse post-crisis.

\section{The macroprudential approach as proposed by Borio}

To emphasize the differences between mainstream economic thinking about systemic risk and regulation and the macroprudential approach, we rely on a programmatic document of Borio in 2003, in which he outlined his vision of a macroprudential framework. After describing the two frameworks, Borio's terminology of the "cross-sectional-dimension" and the "time-dimension" is used to arrive at a coordinate system that shows and pronounces the different understandings of old and new thinking about systemic risk. A result of this is, that it is possible to identify and extract the core of Borio's thinking and to relate the competing understandings and applications of cycles in financial economics to individual quadrants in the coordinate system.

\section{Old Systemic Risk thinking}

Borio describes the old approach to systemic risk and financial regulation as largely microprudential. The core tenets of it, according to him, are (1) very short risk assessment time horizons, (2) a static view of instability, (3) risk as mostly exogenous, (4) structurally illiquid portfolios as a key source of vulnerability and amplification and (5) it is completely rooted in economic

\footnotetext{
${ }^{5}$ It is important to note that the mere contemplation of economic ideas itself does not mean that they will be translated into regulation in a direct manner. Take for example the problematic with too-big-to-fail institutions. Their regulation has been largely due to consideration of political actors on the financial and political costs of another bank bailout, yet very little economic arguments were considered while introducing new regulations. The idea of preventing another large scale bank bailout does not provide a clear policy proposal and has in fact produced two rather different regulations (SIFI sur-charges and resolution regimes for SIFIs). TBTF regulation shows, that ideas, no matter their origin, are translated and changed during the process of implementing them into actual policy.
} 
microfoundations and therefore focuses on the micro-level (Borio 2003: 5). The short time horizons of risk assessment (1) that financial institutions operate in take away the possibility to think about risk as a long term phenomenon. This vision of the world leaves the users of this model with a static view of instability (2) which paints "the financial system [...] as initially vulnerable; suddenly, a shock occurs" (Borio 2003:5) that puts sudden, unexpected and mostly unseen pressure on the system from the outside. This connects to the location of systemic risk (3), which is endogenous only insofar as it is amplified through the financial system, but it always has an external initial shock as a cause. Borio identifies as a key source for this initial vulnerability and the within-system amplification (4) structurally illiquid portfolios.

The result is an understanding of risk in which it is always the failure of an individual institution, deriving from their subpar portfolios, which spreads through a variety of contagion mechanisms to the system level and it is "[i]nterlinkages through balance sheets and overreactions driven by imperfect information [which] are seen as key channels" (Borio 2003: 5). Risk is evaluated not on an aggregate genuinely systemic level but on the level of the relative riskiness of individual borrowers or instruments. The last aspect (5) that Borio mentions concerns the ontology of economics inherent in this view, which is completely rooted in economics micro-foundations; it puts the individual actor at is analytical and theoretical starting point.

\section{„New Systemic Risk Thinking“}

The new way of looking at systemic risk according to Borio takes a fundamentally different vantage point. Stemming from Minsky's "Financial Instability Hypothesis” (Minsky 2011), systemic risk is endogenous to the financial system and develops and grows over time. Borio applies longer time horizons (1) of three years11 (Borio 2003: 12) and allows "for multiple horizons, in the conviction that the precise timing of a crisis is essentially unpredictable" (Borio 2003: 12). Instability (2) or the system's vulnerabilities seen on a longer time scale, then, become far less static and turn from something external to a variable that builds-up over time. At first, there is a build-up phase which "is normally characterised by booming economic conditions, benign risk assessments, a weakening of external financing constraints, notably access to credit, and buoyant asset prices" (Borio 2003: 6). Systemic risk (3) thereby becomes an inevitable feature of the system that grows as the system develops. The aforementioned conditions "[promote] and [mask] the accumulation of real and financial imbalances; the system becomes overstretched" (Borio 2003: 6) and risk becomes a 
genuinely endogenous element of the financial system - "[t]he boom sows the seeds of the subsequent bust" (Borio 2003: 7). Rather than focusing on structurally illiquid portfolios (4), the focus of the new framework is on "instances...where systemic risk arises primarily through common exposures to macroeconomic risk factors across institutions" (Borio 2003: 6, italics in original). These exposures are "associated with asset prices, sectoral, regional or macroeconomic developments" (Borio 2003: 4), making the source of systemic risk endogenous to the financial system, located on the asset side of balance sheets, as this is where the risks are actually building up. The focus is not on individual institutions (5), but the system as a whole.

This departure from micro-foundational assumptions leads Borio to the difference between "systematic risk", which he also calls "system-wide macro risk" and "common exposure" (Borio 2003: 10), and "idiosyncratic risk", which is the risk individual institutions face and represent (Borio 2003: 3, 6, 8, 10). However, Borio speaks of the caveat that there is a difficulty "to measure how the absolute level of systematic (system-wide) risk evolves over time” (Borio 2003: 8), which is the result

of his contemporary literature being mostly about cross-sectional issues, which itself stems from the lacking relevance of time in the dominant neoclassical framework.

\section{The Cross-Sectional and the Time Dimension}

In order to show and emphasise the differences between the two approaches, Borio applies two dimensions to the two lines of thinking about systemic risk to arrive at a coordinate system. This system is made up of the new \& old systemic risk and the two dimensions of the "cross-sectional dimension of risk" (across industries and financial institutions) and the "time dimension of risk" (e.g. amplification mechanisms, cyclical elements based on the endogeneity of risk). 


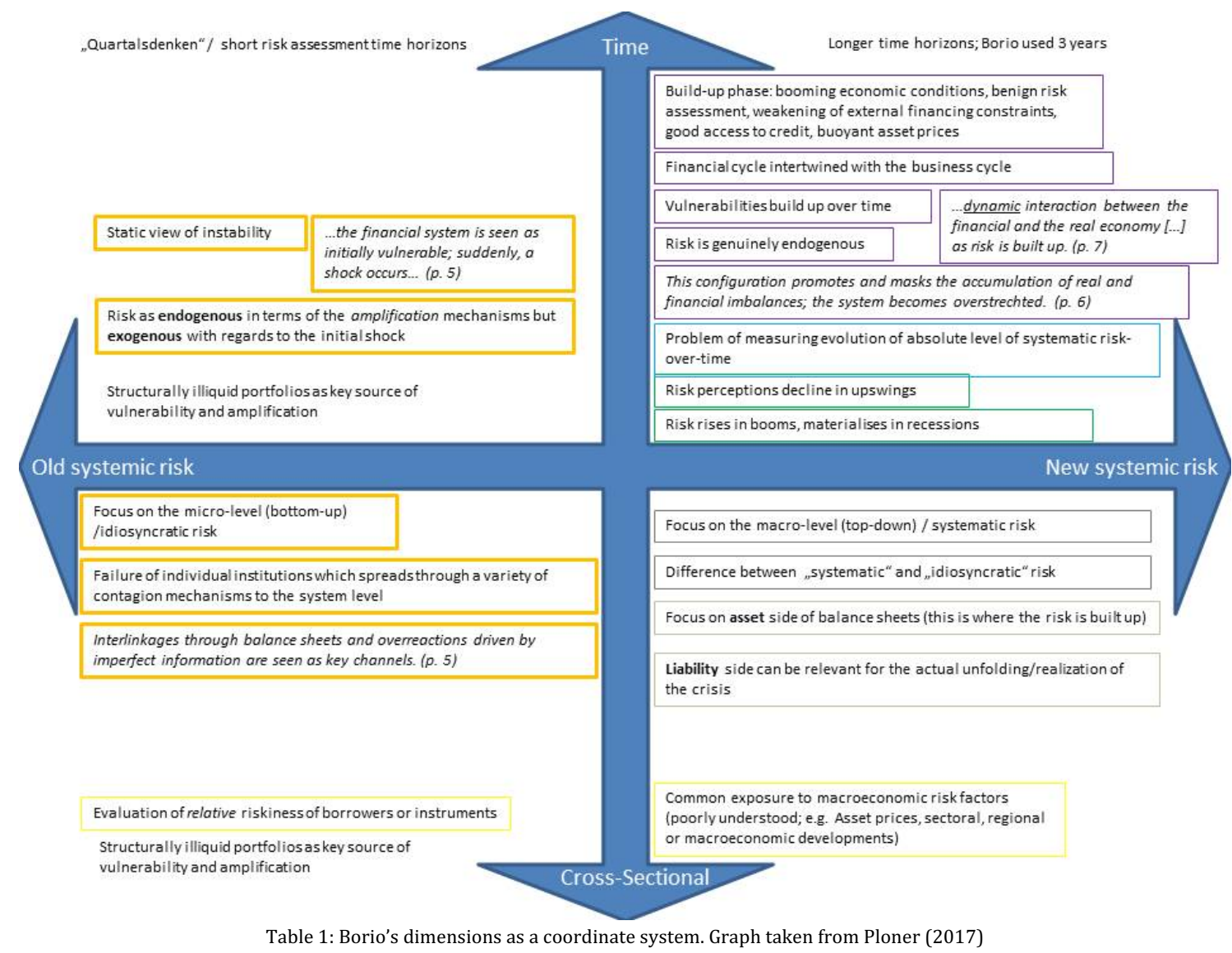

Table 1 depicts these different understandings of systemic risk in these two dimensions, which shows the emphasis of Borio on the centrality of the time dimension. And it is this understanding of the relevance of time and, ultimately, cyclicality where "the macroprudential perspective comes into its own" (Borio 2003: 11). The concept of a financial cycle directly and fundamentally opposed the then dominant microfoundational regulatory paradigm in that it urged regulators to move away from a micro-level approach and towards the premise that there are effects on the system-level, the macrolevel, that warrant a different approach to regulation.

Vulnerabilities and risks were seen to continuously build up over time as the cycle progresses. Borio's insistence on the cycle and the prevalence of the time dimension of risk contrasts starkly with the old understanding of systemic risk. Instruments that try to deal with this time-dependent systemic risk, therefore, differ fundamentally in their functioning and their objectives. The old microprudential perspective wants to "limit distress of individual institutions" (Borio 2003: 2) and tries to keep contagion in check. Time is barely relevant with a static view of instability and an exogenous understanding of risk. The financial cycle-based, macroprudential perspective on the other hand, 
puts time centre stage and accepts the existence of system-wide risks that increase over time.

\section{Analysis of the post-crisis discourse}

\section{Data}

The data for this study was collected via the RePEc ${ }^{6}$ (Research Papers in Economics) database, which is the largest collection of economic publications of all types (beyond academic publications, it also includes publications of institutions like central banks, BIS, IMF, think tanks and financial institutions). The RePEc database was used to find every publication, which as either the terms "systemic risk" or "macro-prudential"7 in either keyword, title or abstract. This process yielded 5732 publications. Beyond the Title, Abstract and Keywords, RePEc also provided relevant meta-data like the author information for each publication.

After the elimination of all duplicates the dataset still has 3716 entries in the time period from 1988 until 2017. Of these 3716, 2397 documents were downloaded and are available for full-text analysis via STM. After the dataset was downloaded every author within the dataset was coded based on his/her institutional affiliation as given in the document itself. The possible categories for authors are BIS (Bank of International Settlement), IMF (International Monetary Fund), academics, central bankers, private finance, mixed $^{8}$ and others. The author affiliation data was then further used to determine document type in a similar fashion. Documents were coded as purely academic, central banking, international organization, if all the authors belonged to either category. The mixed category includes publications, which are either written by multiple authors with differing affiliations or one author that by himself is mixed.

Graph 1 shows the distribution of documents over time. As expected the number of overall documents increases drastically after the financial crises. The number of academic publications show the strongest increase of all categories, although the number of publications for purely central banking and international organizations work also increases rapidly (especially in the run-up to Basel III). Another interesting observation comes from the delayed engagement of cooperation between different groups of authors. Mixed documents seem to increase two years later than other types of documents and, in contrast to pure CB and IO documents, seem to keep increasing.

\footnotetext{
${ }^{6}$ http://www.repec.org/

${ }^{7}$ Variations of the terms were also used for the search

${ }^{8}$ Mixed authors have either more than one affiliations within one document or have different affiliations in two different documents.
} 


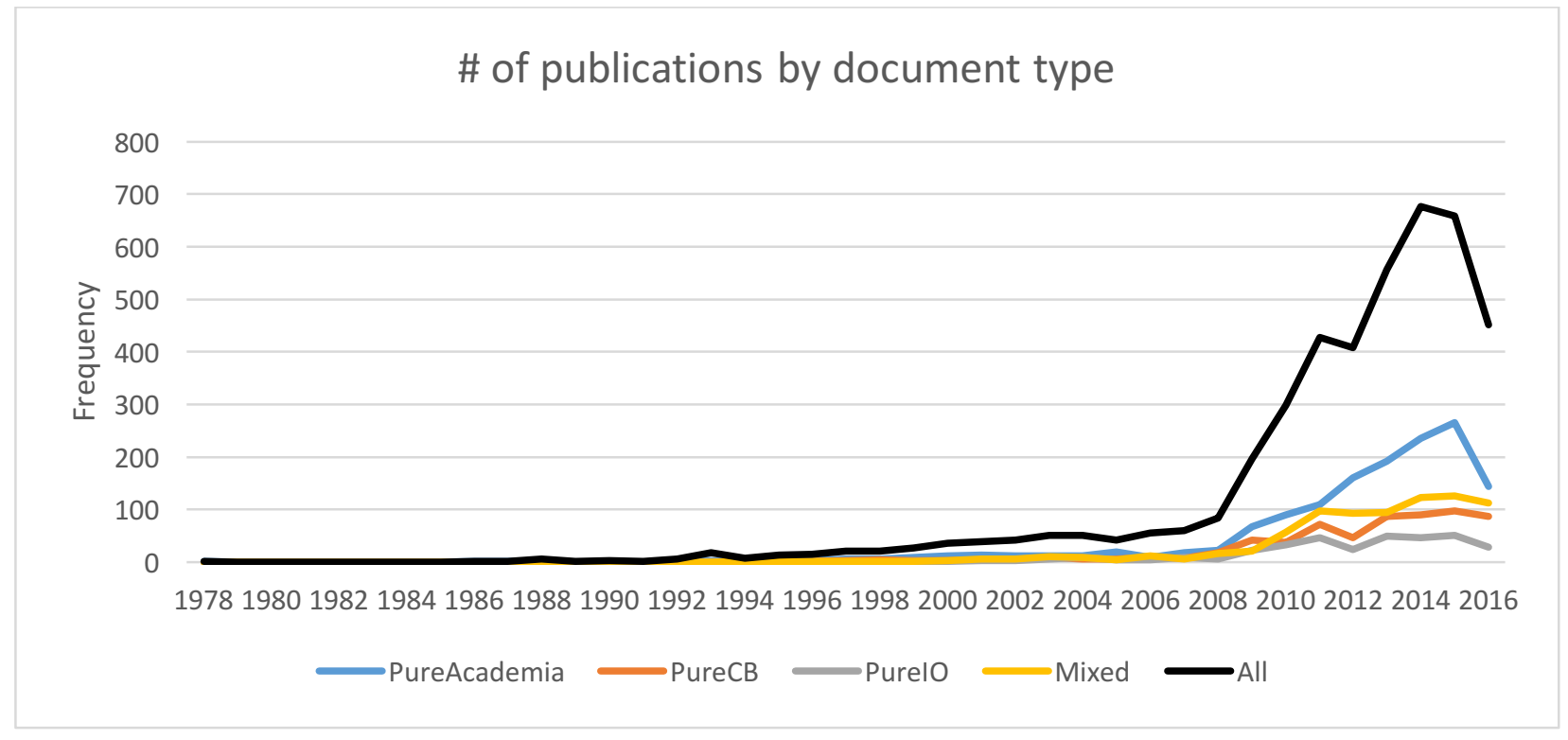

Graph 1: Publication distribution over time

The first result from our descriptive statistic was, that there is surprisingly little overlap between publications that have systemic risk in their keywords, abstracts or titles and the ones that have macro-prudential. Out of the 3716 documents, our search found 2119 publications that only deal with systemic risk, while 1193 deal with macroprudential regulation. The remaining 404 documents have both search terms in either keywords, title or abstract. This is surprising, since it is commonly assumed in the literature that macroprudential regulation is the regulation of systemic risk, yet, if only $10,8 \%$ of all documents on the topic of systemic risk and macroprudential regulation deal with both issues at once, this seems unlikely. Due to the relatively small overlap between systemic risk and macroprudential, we chose to split our sample in three subsamples: systemic risk, macroprudential regulation and the overlap between the two.

The first difference between the three samples can be seen once the document type per sample is calculated. The SR sample is mainly populated by academic publications, the second largest group being mixed publications, while the overlap and MPR samples share a similar document type distribution. In both samples, the biggest group are mixed publications, while academia and central banks are the both equal in size. Considering the size of the SR sample, compared to MPR and overlap, it is somewhat unsurprising to see that the distribution of document types for the entire sample resembles the SR distribution. Nonetheless, the first descriptive results already shows that the systemic risk and macroprudential regulation discourses are populated by two different types of economics. Considering the fact that the overlap sample consists of publications with "systemic risk" 
and "macroprudential regulation" in either keywords, title or abstract, it is interesting to see that the overlap resembles the MPR sample more than the SR sample.
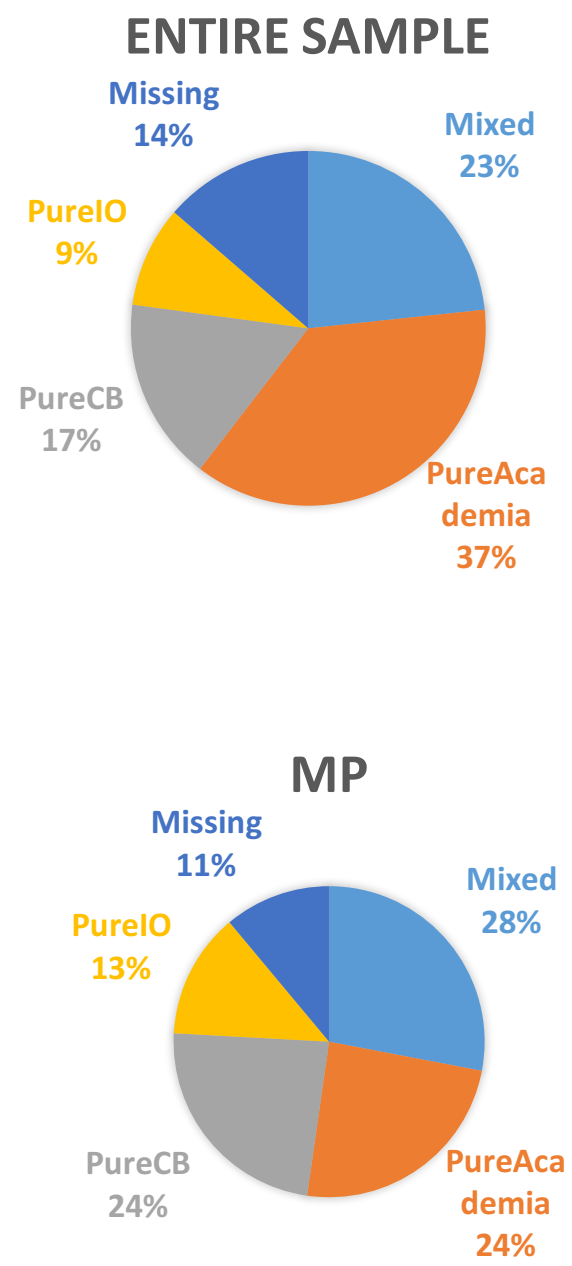

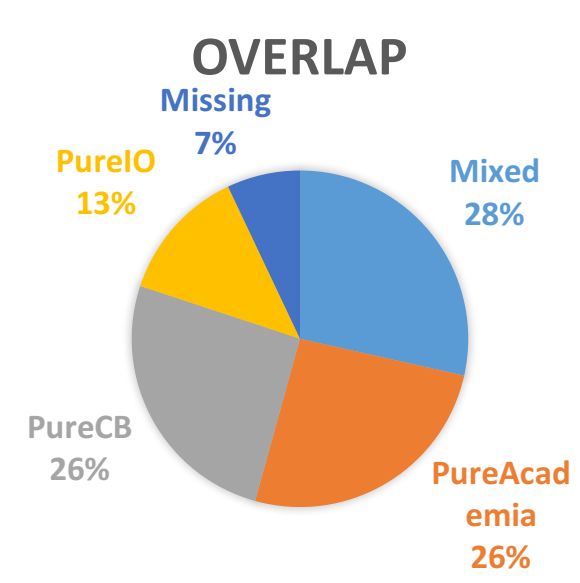

SR

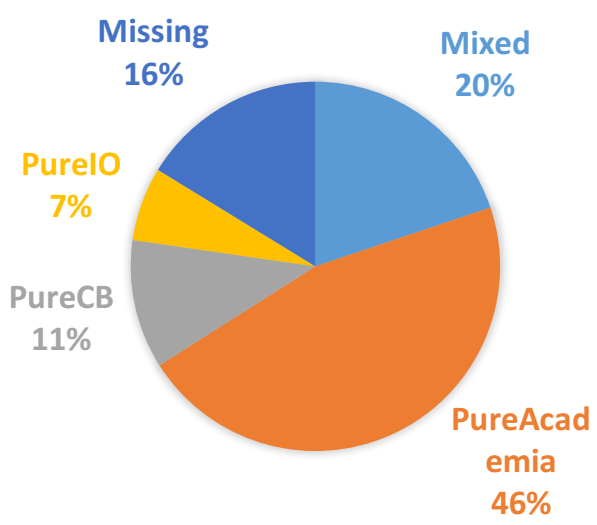

Figure 1: Publications type for overall samples and subsamples

Graphs 3-5 shows the publication distribution over time for each subsample separated into our document types. Systemic risk includes a fair amount of publications even before the crises, even more so then the other subsamples. Furthermore, the systemic risk sample is the only sample in which academics engage prior to the crises. Post crises all groups engage heavily in the systemic risk discourse, but the interest of most groups except for academics stagnates around 2010. This is different for the other two subsamples. Both subsamples have rather few publications pre crises and expand massively post crises. Especially interesting is the macroprudential sample and the increasing engagement of mixed and central banking documents. While in the systemic risk and overlap subsamples, the interest of those two groups stagnates, it is increasing for both groups postfinancial crises. 


\section{SR publications}

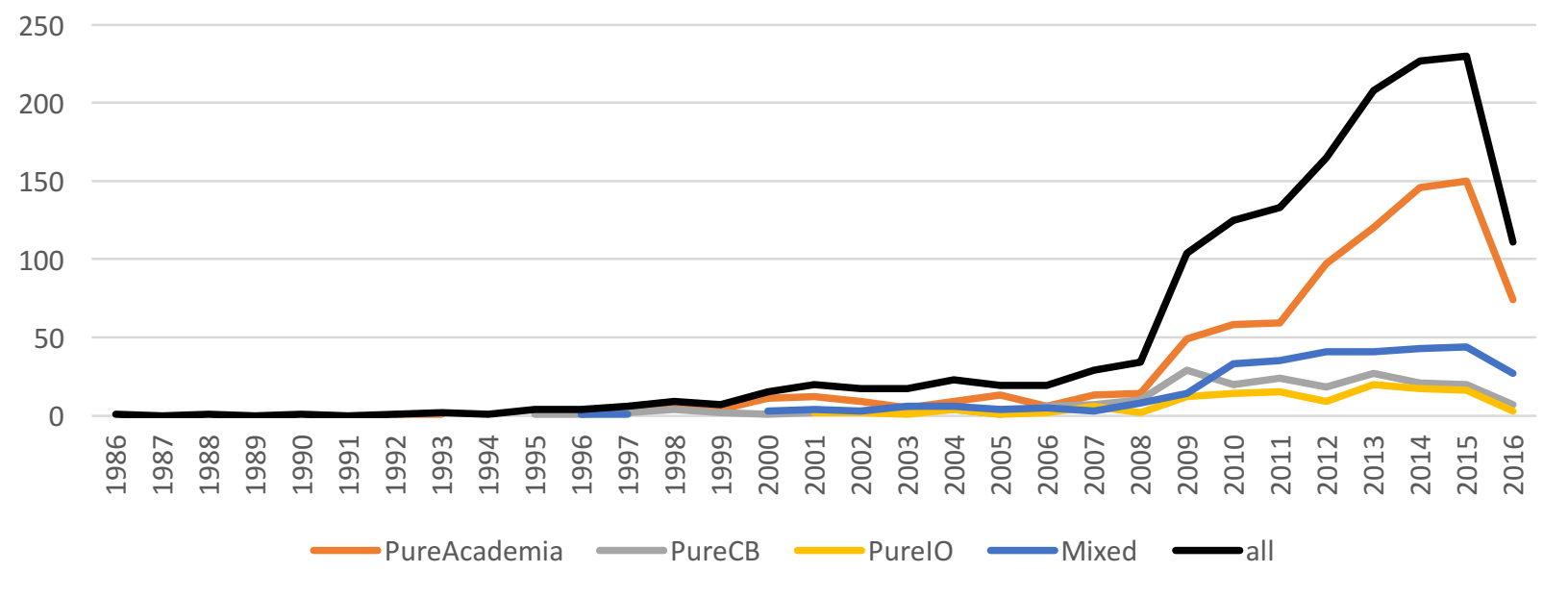

Graph 2: Number of publications of all systemic risk publications

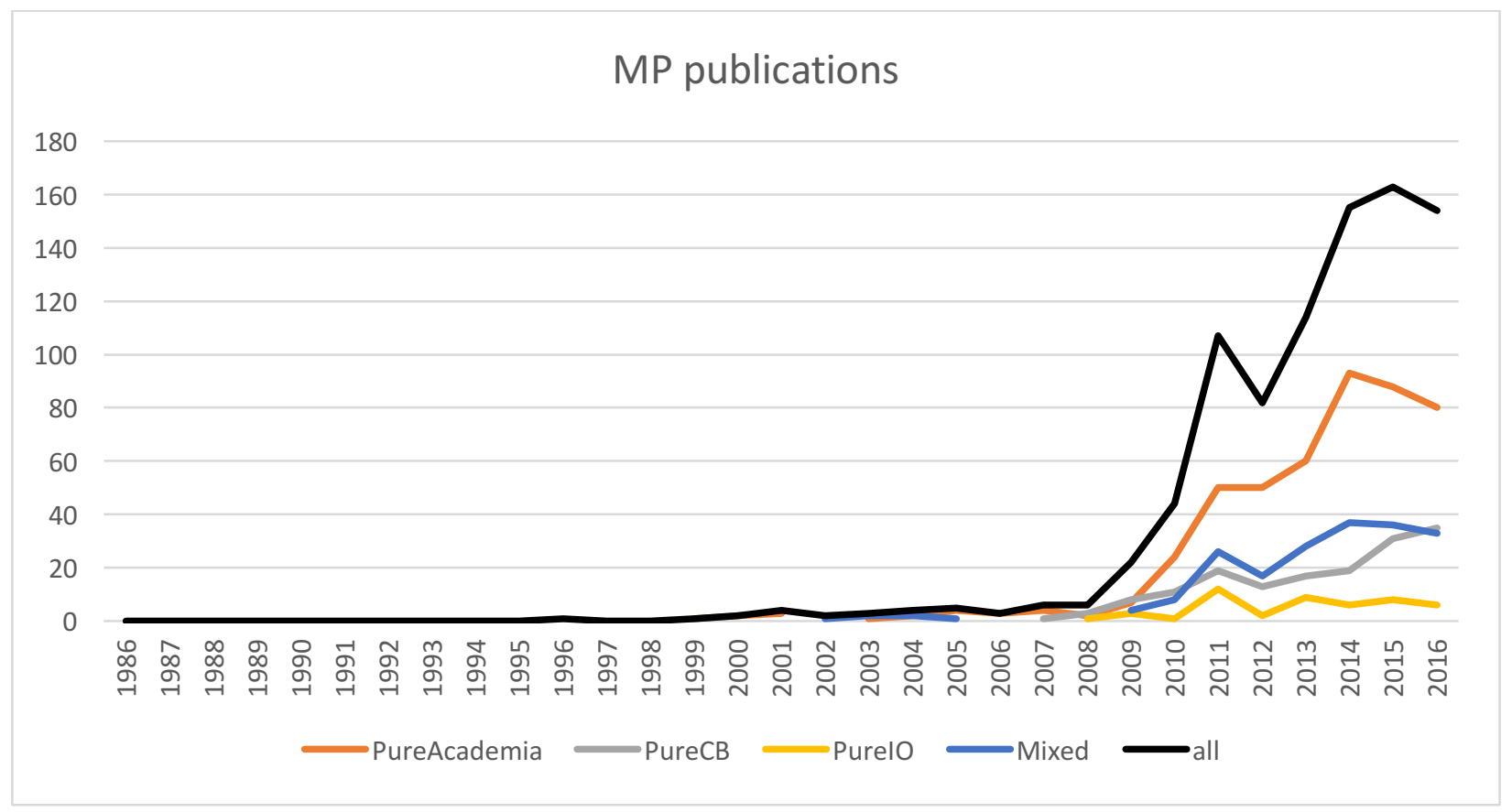

Graph 3: Number of publications of all macroprudential publications 


\section{Overlap publications}

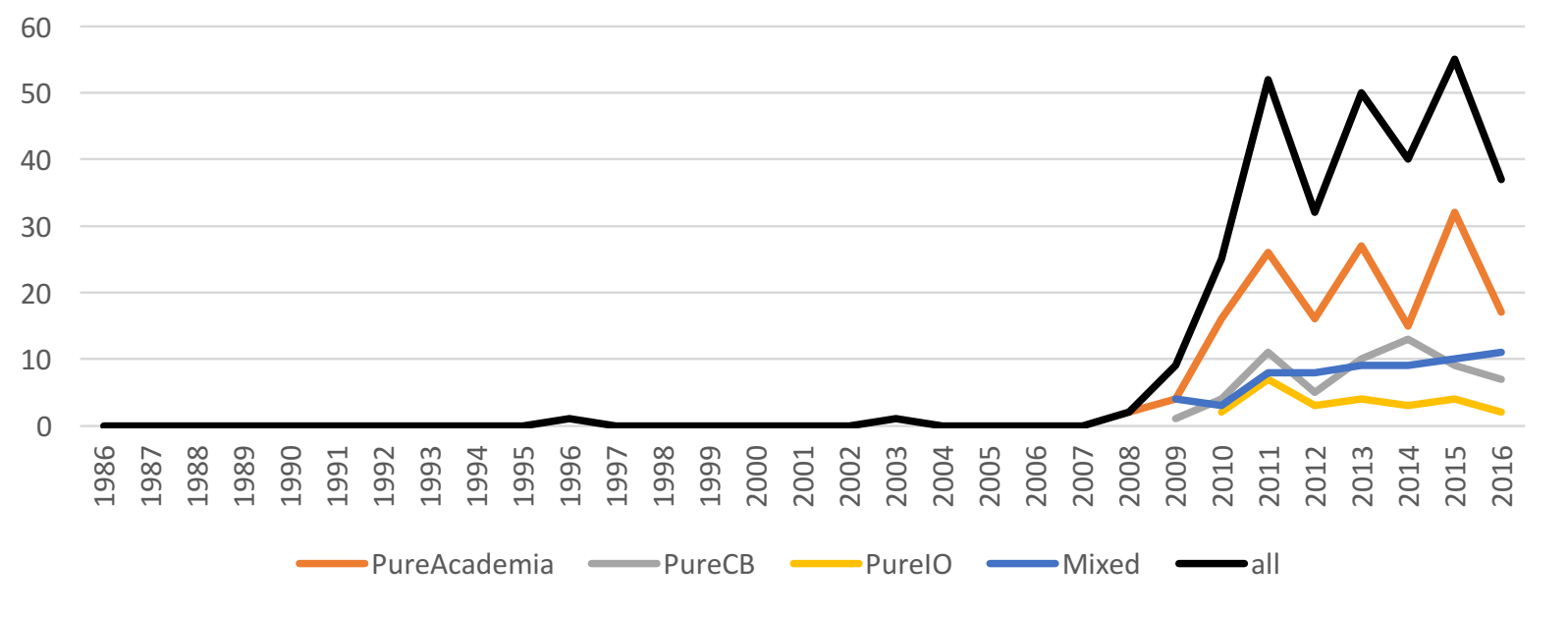

Graph 4: Number of publications of all systemic risk AND macroprudential publications

The high number of documents available for content analysis requires us to utilize quantitative content analysis algorithms. In recent years topic models and more specifically Latent Dirichlet Allocation has established itself as a useful tool for this (Blei et al 2013, DiMaggio et al 2013). The next section will shortly introduce the main advantages of topic models and specifically Structural Topic Modelling (Roberts et al 2014), that is used for our analysis.

\section{Method}

Topic modelling in its basic form assumes that every document is a distribution over topics and every topic is a distribution over all words within the text corpora. This assumption is backed up by what is called the "bag-of-words" assumption, which assumes that the order of words is unimportant for the analysis of the document content. This allows LDA to use a two-step generative process to produce its result. First, every topic and every document is allocated a random distribution over words and topics (Blei et al 2012; Rosen-Zvi et al 2004). These distributions are than filled in a generative process, which is given the number of topics and the frequency of words in each document as an input. To fit the random distributions of topics to the observed dataset Gibbs Sampling is usually employed (Blei 2012). The Gibbs sampling algorithm "estimates the probability of assigning the current word token to each topic, conditioned on the topic of assignment to all other word tokens" (Steyvers and Griffiths 2007,p. 8). The result of the algorithm is that every document is a distribution over the number of topics and every topic can be represented by its most common words. 
Structural Topic Modelling (STM) (Roberts et al 2014) is based on an early extension of LDA named Correlated Topic Modelling (CTM) (Lafferty and Blei 2006). CTM extends LDA since it assumes that topics, which appear frequently with each other are closely correlated with each other. This property is used by STM to allow the inclusion of meta-data into the modelling process. Using this feature and others STM allows for the inclusion of meta-data to influence the prevalence of topics and their correlation with each other. Furthermore, STM includes upgraded statistical tools, which make the algorithm less parameter dependent and produces the same results for every text corpora on one machine. One additional benefit of STM is that it does not only provide the most common words for each topic, but also the most exclusive ones (Bischof and Airoldi 2012; Roberts et al. 2013), thereby vastly improving the interpretability of the respective models.

In this study we employ topic models and more specifically STM as a quantitative content analysis tool. In a first step we run STM with an increasing number of topics for each of the three subsamples. Although, some quantitative measures exist to determine the number of topics, we chose to increase the number of topics in each subsample and determine the number of topics qualitatively9. Before we employed STM, we cleaned the documents with standard text pre-processing procedures ${ }^{10}$.

The resulting topic models are then used to perform two types of analysis. First, a description of all the topics and their evolution over time is conducted. The description stems from qualitatively checking the topics and their content and will only be written out for few topics in this study. The second step involves an analysis over time. Here we take the average topic distribution for each type of document per year. This will allow us to analyze how topics evolved over time and more importantly what kind of economists were engaged in the topic. In addition to topic modelling, we also conducted interviews with economists in central banks, academia and international organizations like the IMF and BIS to further inform and collaborate our analysis ${ }^{11}$.

\footnotetext{
${ }^{9}$ The choice for qualitative checking is mainly due to two factors: First, quantitative measures generally overestimate the number of topics and thus tend to produce topics which are not interpretable by humans. Second, the number of topics generally depends on the research question at hand. In our case we choose topics in the midrange, not too many topics to reduce interpretability by humans, but not too many to disregard important topics.

${ }^{10}$ Words were de-capitalized, all numbers, punctuations and non-Latin letters were removed. Furthermore, a standard stopword list was used to remove the most common words. Afterwards a soft word stemmer was applied to account for conjugation of words. STM also produces word lists of the most exclusive words, hence we removed words that only appeared in 50 documents or less.

${ }^{11}$ In total 5 interviews were conducted
} 
The last step in our analysis is based on the description of Borio's new and old systemic risk thinking. We used his conceptualization of new and old thinking and applied it to our topics, coding them on their particular style of thinking. Separately from new and old thinking, we were particularly interested in the time-dimension of the discourse within each topic. As described above, time-variant analysis is the key factor of new systemic risk thinking, hence we coded each topic based on their use of time-variant or cross-sectional analysis. These two dimensions resulted in four categories a topic could be coded in: new SR thinking with time-variant analysis, new SR thinking with cross-sectional analysis, old SR thinking with time variant analysis and old SR thinking with cross-sectional analysis. Once a topic was coded, all the documents within it were assumed to have the same code. Afterwards a simple summation of all types of documents coded as one of the four categories was done. We conducted $\mathrm{chi}^{2}$ tests on the resulting distributions of document types to verify their statistical significance.

\section{Topic modelling results}

The topic modelling on all three subsamples yielded 17 topics for the systemic risk sample, 18 for the macroprudential sample and 9 for the overlap between the two ${ }^{12}$. Some topics appear in every subsample, since the discourses deal with similar issues. The biggest topic in each subsample deals with the issue of regulatory set ups, which have to either deal with systemic risk or actually conduct macroprudential regulatory tasks. Other topics only appear in two of the three subsamples. The topic of financial networks/interbank contagion and topics dealing with the attribution of systemic risk to institutions can only be found in the overlap and the SR sample, while they are not discussed in the macroprudential sample. On the other hand, early-warning-indicators and stress tests for upcoming crises are not discussed in the systemic risk sample at all. This might be due to the fact that earlywarning-indicators and stress tests are considered as mere number crunching by academia (interview ECB economists May 2016). Then there are topics unique to each sample, the most interesting of which can be found in the overlap sample. Here we find the only topic that actively attempts to evaluate the efficiency and efficacy of macroprudential tools and the only topic that discusses indicators for counter-cyclical regulation.

A closer look into the topics themselves reveals another distinction between the three samples. The publications within the SR sample focus heavily on the use of economic modelling, most notably the use of agent-based-modeling, portfolio models and in later periods' network and contagion models.

\footnotetext{
${ }^{12} \mathrm{~A}$ list of all topics, including their most likely and most exclusive words can be found in Appendix A
} 
The MPR sample on the other hand relies mostly on statistical analysis of markets, mostly used for stress testing, the evaluation of MPR tools like LTVs or early warning indicators. If economic modelling is used, it is mostly used to integrate MPR tools into monetary policy via DSGE models. The overlap sample shows characteristics of both samples. Topics dealing with the evaluation of MPR tools focus on cross-country panel analysis, while topics addressing the SR of institutions and network/contagion problems rely on economic modelling.

\section{Topics regarding too-big-to-fail institutions}

The above overview of post crises regulatory crises indicates that only very few economic ideas have actually been translated into regulation. The biggest regulatory change post crises pertains the regulation of too-big-to-fail financial institutions. The introduction of numerous measures (recovery and resolution, Core capital for G-SIFI, TLAC and MREL), all of which require some sort of measurement on the contribution of financial institutions to systemic risk. These types of measurement can be correlated to multiple topics within our subsamples. In the SR sample the topics of "systemic risk measuring" and "risk estimation \& modelling" pertain to these issues. The MPR sample only includes one topic in this regard, which is mostly focused on cyclical capital regulation. Although this topic deals with cyclical capital regulation, the key problematic in these publications is not whether capital requirements are an effective regulatory tool, rather they contest the idea of cyclical capital regulation as a macroprudential tool. Lastly, the overlap sample includes one topics regarding the SR of financial institutions.

As can be seen in graph 6, every topic regarding too-big-to-fail institutions has some sort of backing from academia and the main regulators of MPR, central banks. The risk estimation and modelling topic is mostly dominated by academics and only after the financial crises do central bankers engage with the topic. Although, pure central bank publications engage with them relatively late after the crises, the increase in mixed publications is most likely due to collaborations between academics and central banks. The topic of cyclical capital regulation only becomes interesting to central bankers and academics alike at 2010-2011, once Basel III was ratified and CCBs were delegated to national regulators. Before that central banks by themselves and international organizations seem to be interested in the topic. Post crises the interest of mixed publications seems to be the first to increase. The topic of attributing SR to institutions becomes popular immediately after the crises to academics and mixed publications alike. 

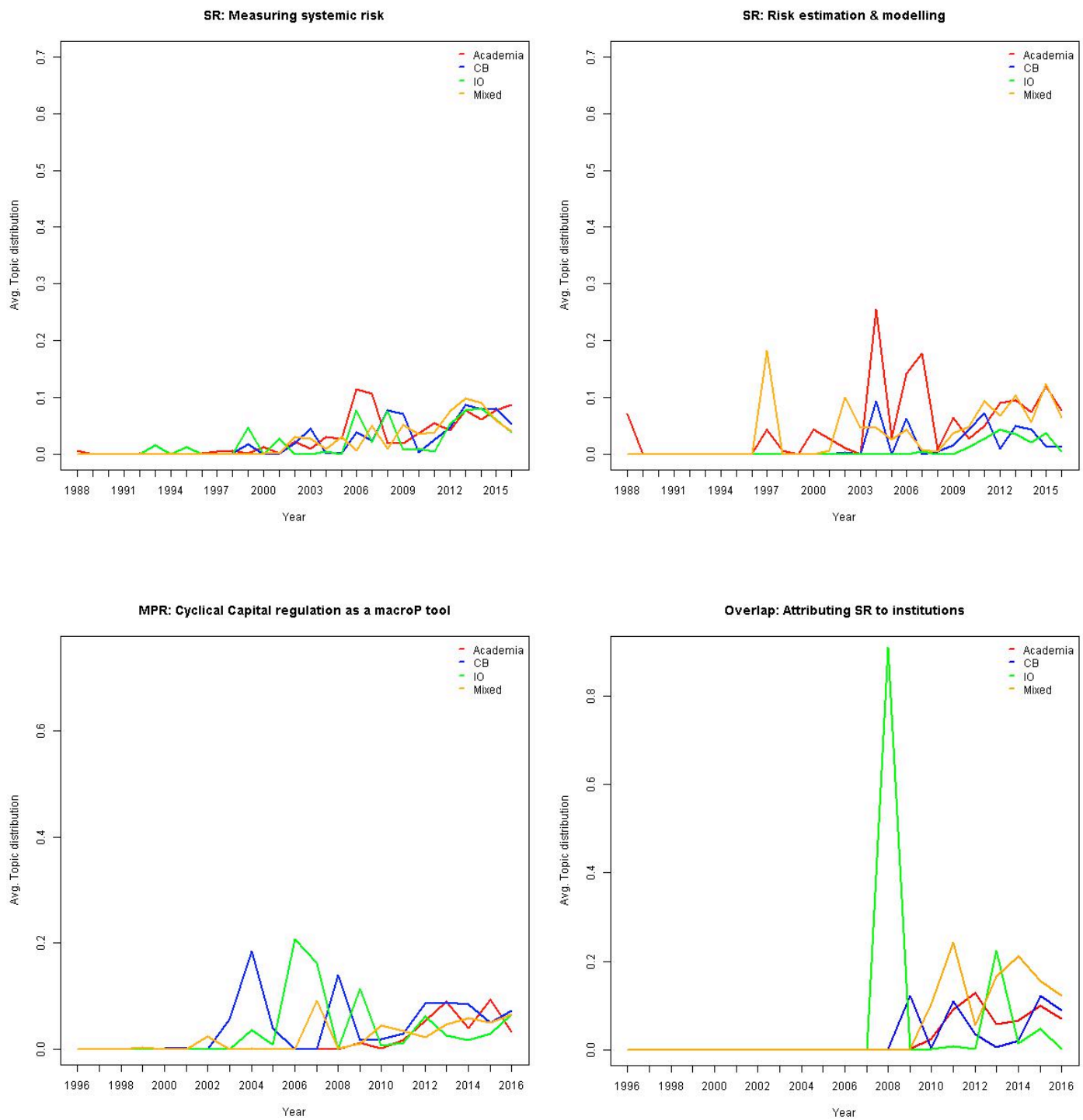

Graph 5: Average topic distribution per year per document type for topics regarding too-big-to-fail

\section{Topics regarding networks, contagion and counterparty risk topics}

The introduction of CCPs and NSFR showcase a different conceptualization of the financial system than the too-big-to-fail problematic. Here, the relation between financial institutions come to the foreground and more importantly, the effects the insolvency of one or more financial institution can have on the entire system. For these types of regulations a few topics can be found in the three subsamples, most of them in the SR sample. There topics on financial networks, interbank contagion and derivatives \& counterparty risks are most prominently connected to CCP regulation. The problematic of counterparty risk is particularly curious, since it changed its most common meaning over the last 30 years. While in the 90's and early 2000's counterparty risk was mainly an issue in 
the context of the payment and settlement system and was mainly an issue for central banks, it increasingly became regarded in the context of derivatives markets or rather what happens in those markets, if a party becomes insolvent. The other subsamples offer few topics on this issue, only in the overlap sample were we able to find a topic regarding networks and contagion.
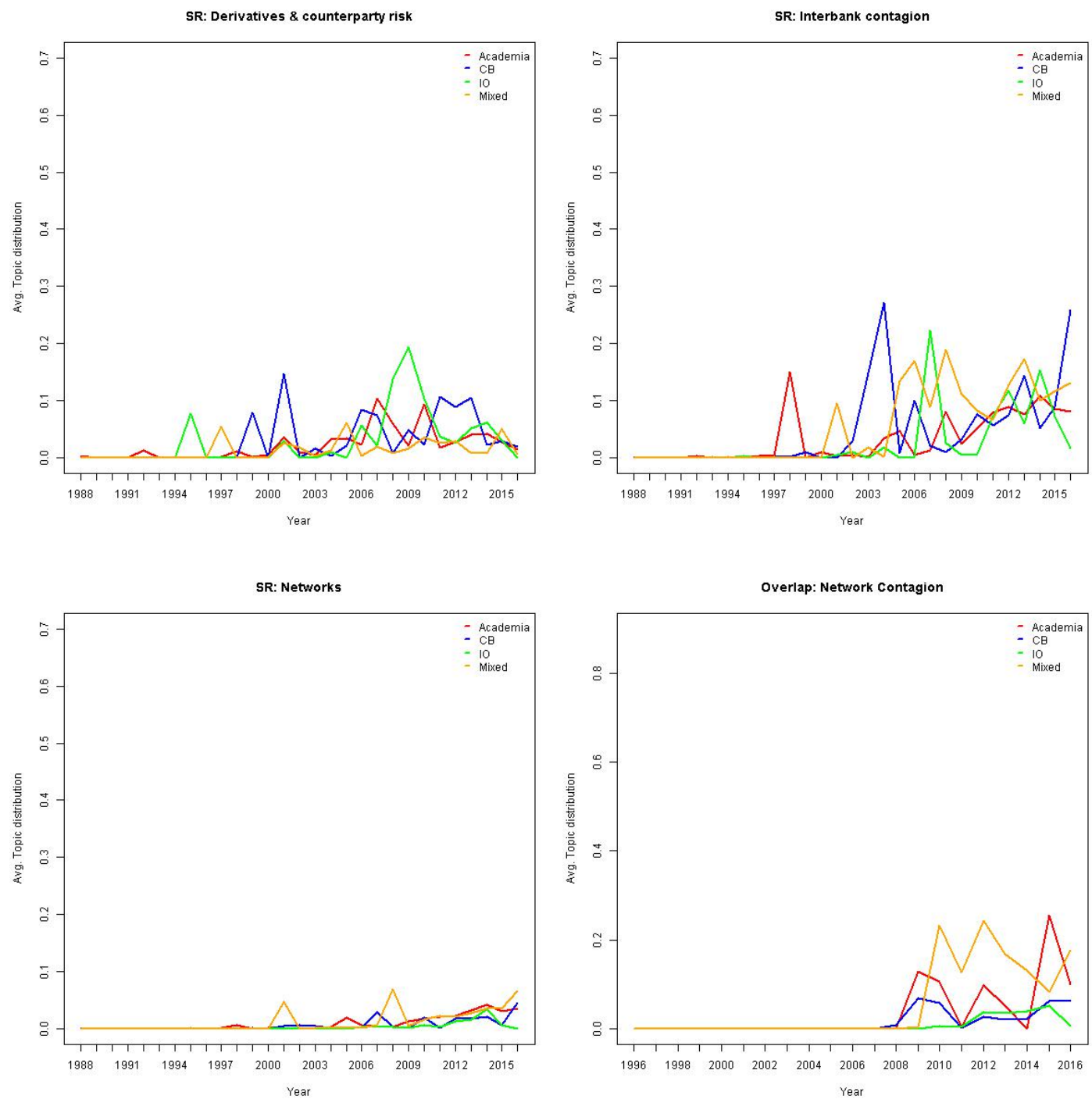

Graph 6: Average topic distribution per year per document type for topics regarding networks and contagion

The topic of derivatives \& counterparty risks becomes of interest to central bankers and academics alike even before the financial crises itself occurs with a short drop during the crises. After the crises the topic gets picked up again shortly by academics until 2011, while central bankers interest in the topic increases only after 2010. The topic of interbank contagion on the other hand starts to garner interest much before the financial crises of 2008. Mixed publications begin at 2004 to show interest 
in the topic, while purely central banking and academic work increasingly focuses on the topic after the financial crises. The closely related, yet different topic of networks in the SR sample is only a small topic, but it is important since it provides much of the mathematical backing for the contagion literature. Here, we find mainly academic publications, dealing with questions of how network topology and network effects impact the financial system at large. A similar pattern can be observed in the overlap sample. The topic dealing with networks and contagion is mainly populated by mixed and academic publications. This is especially interesting, since the overlap subsample overall is mostly populated by non-academic publications.

\section{Topics regarding cyclical concepts}

When it comes to topics dealing with the cyclical nature of the financial system (the key component of the macroprudential idea according to Borio 2003), very few topics can be found. None of the topics within the SR sample deal with the financial cycles (or any other cyclical concept like credit cycles/business cycles etc.). Only sporadically can publications be found that directly deal with cyclical issues, mainly revolving around asset-price cycles and the business cycle. Even more surprising than the absence of cyclical concepts in the SR sample is that the MPR subsample does not show a clearly demarcated financial cycle topic either. Most of the topics within the MPR sample merely assume that a cycle exists and that something has to be done about it, but only rarely is the concept of the financial cycle directly addressed. Hence, we chose to take a closer look at those topics that tacitly assume that the financial cycle exists. Among those is the previously discussed topic of cyclical capital regulation, the topic on early warning indicators, a topic on loan-to-value ratios and lastly in the overlap sample, the topic on indicators of counter-cyclical regulation.

The cyclical capital regulation topic is as described above, but corresponds nicely with the indicator topic within the overlap sample. In this topic central bankers are immediately interested in the issue after the financial crises and are continuously afterwards, most likely due to the fact, that Basel III delegates the implementation of counter cyclical capital buffers to national regulators. The topic of early warning indicators is a peculiar one, since it exhibits an early interest of academics and mixed publications, a pattern, which makes them more likely to become institutionalized. This is a possible explanation as to why the credit to GDP gap became accepted as a measure post-crisis (Drehmann et al 2009). The last topic that tacitly assumes the financial cycle, without actually conceptualizing it is the topic of loan-to-value (LTV) ratios. LTVs were already in use prior to the financial crises in some countries, yet the only authors interested in the topic seem to belong to international organizations (here the IMF is most notable, since the conduct a number of comparative studies on LTVs). 


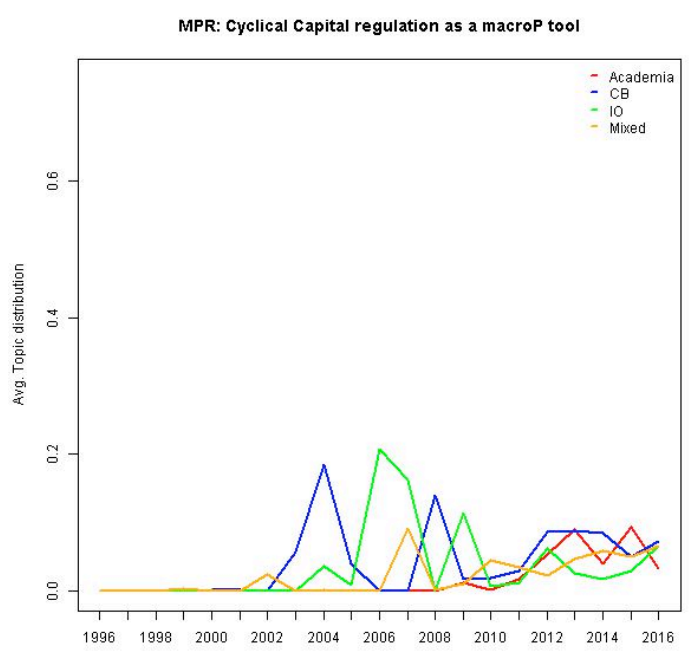

Year

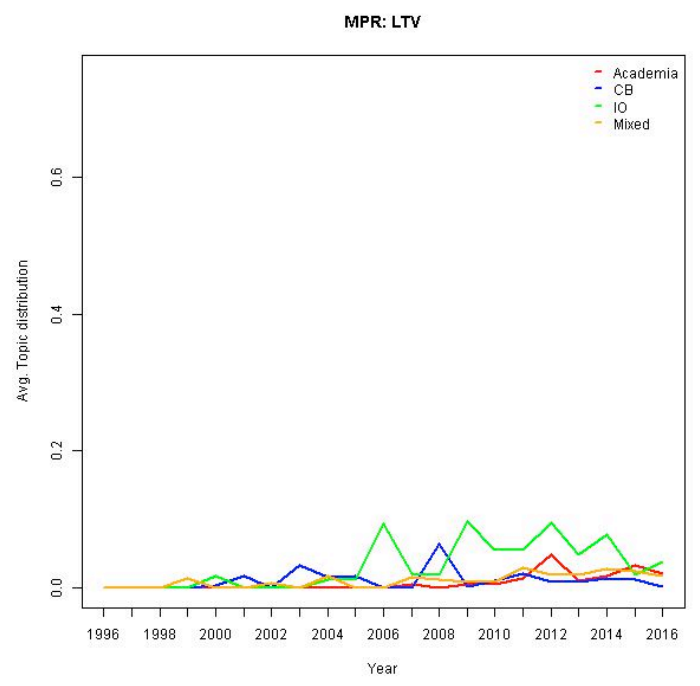

Graph 7:Average topic distribution per year per document type for topics regarding cyclicality
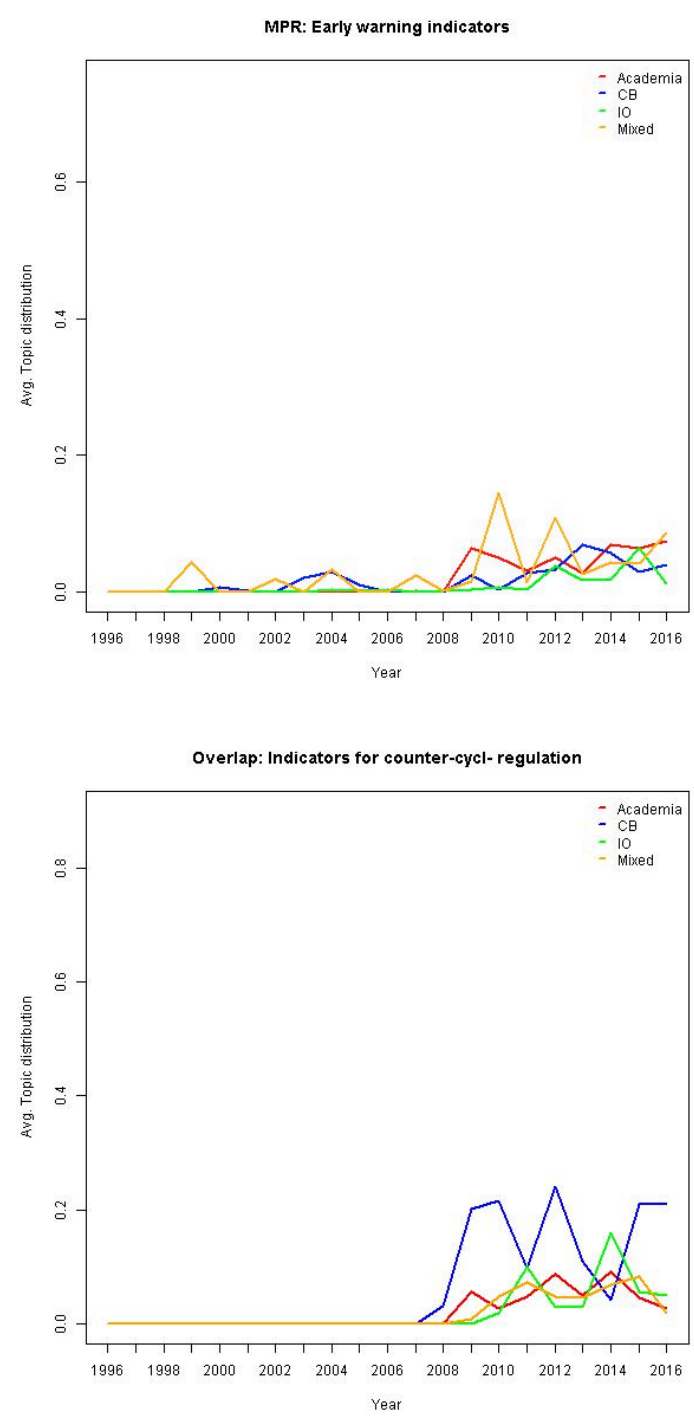

\section{Old vs new systemic risk thinking}

Our comparisons between new and old systemic risk thinking can be summarized in Figure 2 . Documents in topics, which have been coded as part of the new systemic risk thinking and utilize time-variant analysis are the biggest outliers. Together they produce a distribution, which shows resemblance with the MPR and overlap distributions in Figure 1. Purely academic publications seem to not engage with new systemic risk ideas, if they are combined with time-variant analysis. This becomes particularly obvious, when these publications are compared with new systemic risk 
thinking, but still utilize cross-sectional modes of analysis. In these publications academics are much more represented than in its time-variant counterpart.

Another indication for the unique combination of new systemic risk thinking and time-variant analysis is the category of old systemic risk thinking and time-variant analysis. In this category, as well as the category of old systemic risk thinking and cross-sectional analysis, we find a similar representation of academics as in the entire sample. To verify these results we performed $\mathrm{chi}^{2}$ tests on the below distribution and found them to be statistically highly significant ( $p$-value $<0,0001$ ). We further performed the same analysis on each of the three subsamples and have found similar results, which are mostly statistically significant $(0,8>$ p-value $>0,0001)$

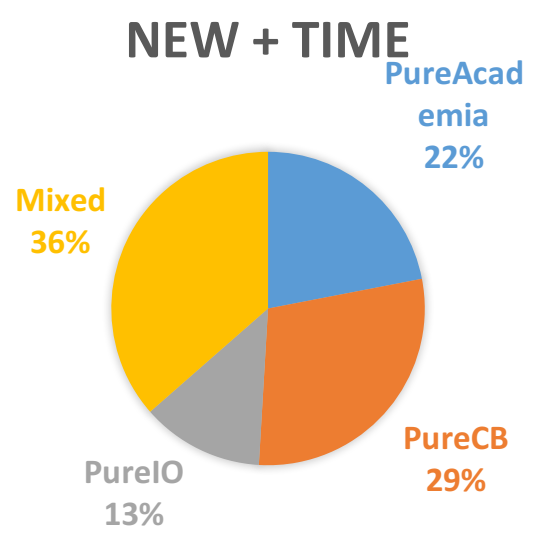

OLD + TIME

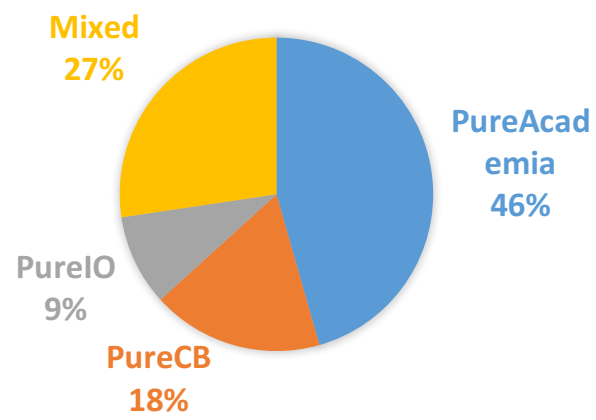

NEW + CROSS

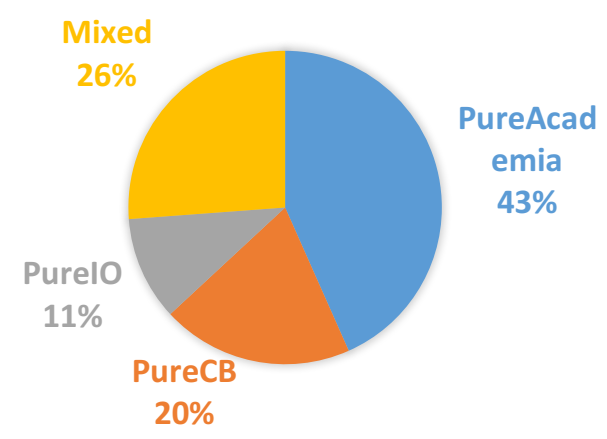

OLD + CROSS

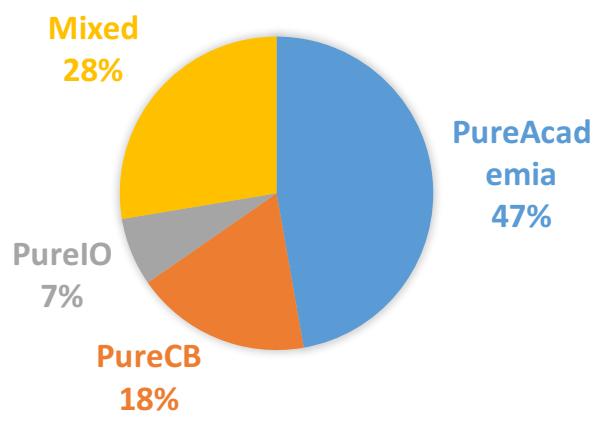

Figure 2: Pie charts of accumulated topics based on their coding in new/old systemic risk thinking and crosssectionality/time-variance 
The results of our analysis are quite interesting for the academic backing of the epistemic claims of new systemic risk thinking. If as Borio stated in the immediate aftermath of the crisis, everybody had indeed shifted towards new systemic risk thinking and macroprudential regulation (Borio 2009) ${ }^{13}$, one would expect every document type to shift towards MPR. Yet, figure 2 shows that the topics mostly concerned with new systemic risk thinking and time-variant analysis are most heavily populated by non-academics and mixed authors, while all the other combinations show similar distributions of publications types as the overall sample. More over the key distinction between does not seem to be new systemic risk thinking per se, but rather the time variant analysis in combination with new systemic risk thinking.

\section{Discussion}

Although the above analysis does not exhaust all of the topics we were able to find via topic modelling, we were still able to show that certain ideas were preferentially treated by certain groups of economists. Ideas surrounding the cross-sectional resilience of the financial system compared to topics, which included a time dependent analysis, were uniformly backed by the academia and largely backed by the regulators themselves. Time variant topics dealing with new systemic risk thinking on the other hand were rarely or only partially backed by academia. The lack of backing by the scientific community was problematic for regulators during the epistemic battle in the aftermath of the financial crises. During the time of post crises uncertainty epistemic power over the status of the world, becomes an invaluable resource for actors to implement their view of the economy. The most valuable resource in these battles is the backing of epistemic claims by academia, since it garners its epistemic authority from the larger position of science as the arbiter of truth in society, a resource, which had to be largely unavailable to macroprudential change agents during the discussions prior to Basel III and other regulatory changes.

Our analysis improves on the current literature on the macroprudential ideational shift by actually providing an overview of when, what kind of epistemic resources were available for which macroprudential idea. The analysis clearly shows that not all macroprudential ideas are equal. Some were backed by academia at different points in time, while others were denied the backing of the scientific community or for that matter regulators themselves. The parts of the macroprudential idea concerning contagion seems to be the only one that found clear success in the post crises regulatory process. The other three parts, herding, fallacy of composition and especially the endogenous

\footnotetext{
${ }^{13}$ He proclaimed that « we are all macroprudentialists now" (ibid).
} 
financial cycle have been largely ignored. Even more surprising than the lacking translation of the three other parts of macroprudential is the lack of discussion on these issues in the macroprudential sample itself. The financial cycle in particular was described by Borio as the moment where "macroprudential comes into its own" (Borio 2003, 11), yet the financial cycle is at best a tacit assumption in most topics within the macroprudential sample. Even if one includes the overlap, the situation does not improve.

Considering the epistemic standing of the financial cycle in academia and the macroprudential discourse itself, it is unsurprising that so far only few new regulations have been implemented regarding the dampening of the cycle. As described above the only regulatory change that could deal with the financial cycle, or to be more precise the credit cycle, are counter-cyclical capital buffers. CCyB are mostly aimed at increasing the resilience of the financial system prior to a financial crises and not towards actually dampening the financial cycle itself. Furthermore, recent studies on the effect of capital regulation on financial stability have shown that capital requirements do not prevent crises, rather they only reduce the welfare costs once a crises has occurred (Jorda et al 2017).

The analysis of publications types for old/new systemic risk thinking and time-variant/crosssectional topics indicates, that the main issue with new macroprudential ideas is not their "newness", rather it is the combination of time-variant analysis and new ideas, which appears to be the biggest obstacle for academic engagement. The most likely explanation for this is that academic economists are heavily invested in modelling approaches, which are still unable to handle the endogeneity of the financial cycle (Thiemann et al 2018). Our analysis shows that academics do not engage in topics, which include the financial cycle in general, even if they only include it as a tacit assumption. The analysis further shows that the combination of new systemic risk ideas and time variance is unique in the sense that it is the one, which differs significantly from the overall distribution in the sample. These results indicate that it is not only specific topics within the macroprudential discourse that are denied backing by academia, rather entire modes of analysis and thinking are rejected.

\section{Conclusion}

This paper has investigated the macroprudential discourse and its evolution since the 1990s. We employed structural topic modelling to identify important topics within the macroprudential and systemic risk discourse and determined the engagement of various types of economists in these topics. By contrasting these topics with the ideal type macroprudential framework, outlined by Borio 
2003, and the post-crises regulatory reforms, we were able to show that only ideas that follow a cross-sectional style of analysis and had the backing of academic economists were implemented.

Beyond the above-mentioned result, we were also able to provide a wholesale overview of the macroprudential and systemic risk discourse post-crisis; showing that the two concepts of systemic risk and macroprudential regulation are not synonymous to each other. Rather, both discourses are focused on different topics and only occur together in a small overlapping sample, with academic economists mostly focusing on systemic risk, and economists in central banks on the implementation of macroprudential regulation. In addition to identifying and characterizing the divide in population of these discourses, we were also able to show that papers on systemic risk mostly remain wedded to "old systemic risk" thinking in Borio's terms, and that those papers on macroprudential regulation treat the intertemporal dimension of new systemic risk thinking rather implicitly, not providing explicit models for the endogenous growth of systemic risk over time. Whatever the reason for this finding, be it the continuous neglect of historical time in neoclassical economics (but s. Brunnermeier and Sannikov 2014) or the opposition to the concept of the financial cycle due to its implication for simple representative rational agent modelling, this finding is worrisome. It implies that an academic justification for anti-cyclical regulation is hardly forthcoming, endangering the project of anti-cyclical regulation in the long run. 


\section{References}

Baker, Andrew. 2013a. The New Political Economy of the Macroprudential Ideational Shift. New Political Economy, 18:1, 112-139

Baker, Andrew. 2013b. When new ideas meet existing institutions: why macroprudential regulatory change is a gradual process. In: Great expectations, slow transformations: incremental change in post-crises regulation. Moschella, Manuela, Tsingou, Eleni. 2013. ECPR Press, Colchester UK

Baker, A. 2014. 'Macro-prudential Regulation' in: D. Muegge (ed), Europe and the Governance of Global Finance. Oxford: Oxford University Press, pp. 172-188.

Blyth, Mark. 2013. Paradigms and Paradox: The Politics of Economic Ideas in Two Moments of Crises. Governance: An International Journal of Policy, Administration, and Institutions, Vol 26, No. 2, April 2013, p. 197-215

Blyth, M. 2002. Great transformations: Economic ideas and institutional change in the twentieth century. Cambridge University Press.

Bischof, J., \& Airoldi, E. M. 2012. Summarizing topical content with word frequency and exclusivity. In Proceedings of the 29th International Conference on Machine Learning (ICML-12) (pp. 201-208)

Bisias, D., Flood, M., Lo, A. W., \& Valavanis, S. 2012. A survey of systemic risk analytics. Annual Review of Financial. Economics, 4(1), 255-296.

Blei, D. M. 2012. Probabilistic topic models. Communications of the ACM, 55(4), 77-84.

Blei, D. M., Ng, A. Y., \& Jordan, M. I. 2003. Latent dirichlet allocation. Journal of machine Learning research, 3(Jan), 993-1022.

Borio, C. 2003. Towards a macroprudential framework for financial supervision and regulation? In BIS Working Papers No. 128

Brunnermeier, M. and Y. Sannikov. 2014. A Macroeconomic Model with a Financial Sector. American Economic Review vol. 104, no. 2, February 2014, pp. 379-421

Carstensen, M. 2011. 'Paradigm Man vs the bricoleur: bricolage as an alternative vision of agency in ideational change'. European Political Science Review, 3, 1, pp. 147-167.

Crockett, A. 2000. Marrying the micro-and macro-prudential dimensions of financial stability. BIS speeches, 21. 
DiMaggio, P., Nag, M., \& Blei, D. (2013). Exploiting affinities between topic modeling and the sociological perspective on culture: Application to newspaper coverage of US government arts funding. Poetics, 41(6), 570-606.

Duffie, D. 2016. Financial Regulatory Reform After the Crisis: An Assessment Post-conference version: 2016 ECB Forum on Central Banking June 2016

Edge, R. and N. Liang. 2017. 'New Financial Stability Governance Structures and Central Banks`. Hutchins Center Working Paper, No. 32.

European Systemic Risk Board (ESRB). 2014. Flagship Report on Macro-prudential Policy. Frankfurt am Main: ESRB Press.

Financial Stability Board 2017.: Implementation and Effects of the G20 Financial Regulatory Reforms 3 July 2017 3rd Annual Report

Fourcade, M. 2009. Economists and societies: discipline and professions in the United States, Britain, and France 1890s to 1990s. Princeton University Press, Princeton

Gieryn, T.,F. 1995. Boundaries of Science. In The Handbock of Science and Technology Studies, edit by Sheila Jasanoff et al., Thousand Oaks, CA: Sage Publications

Gieryn, T.F., 1983. Boundary-Work and the Demarcation of Science from Non-Science: Strains and Interests in Professional Ideologies of Scientists. American Sociological Review, Vol. 48. No.6, pp. 781795

Hall, P. A. (Ed.). 1989. The political power of economic ideas: Keynesianism across nations. Princeton University Press.

Helleiner, E. 2014. The status quo crisis: Global financial governance after the 2008 meltdown. New York: Oxford University Press.

Jasanoff, S. 2011. The practices of objectivity in regulatory science. Social knowledge in the making, 307.

Jasanoff, S. 1987. Contested Boundaries in Policy Relevant Science. Social Studies of Science 17(2): 195-230 
Jasanoff, S. 1990. The Fifth Branch: Science Advisers as Policymakers. Cambridge, MA: Harvard University Press

Jorda, O., Richter, B., Schularick, M., \& Taylor, A. M. 2017. Bank capital redux: Solvency, liquidity, and crisis (No. w23287). National Bureau of Economic Research.

Krippner, G. 2011. Capitalizing on Crises: the political origins of the rise of finance. Harvard University Press, Cambridge

Lafferty, J. D., \& Blei, D. M. 2006. Correlated topic models. In Advances in neural information processing systems, pp. 147-154.

Lombardi, D., \& Moschella, M. 2016. The symbolic politics of delegation: macroprudential policy and independent regulatory authorities. New Political Economy, 22(1), 92-108.Maes, Ivo. On the Origins of the BIS Macro-Prudential Approach to Financial Stability: Alexandre Lamfalussy and Financial Fragility. National Bank of Belgium Working Paper No. 176

Marcussen, M. 2009. Scientization of Central Banking: The Politics of A-Politization. In: Central Banks in the Age of the Euro. Dyson, Kenneth, Marcusson Martin, Oxford University Press, Oxford. pp. 373-391

Moschella, M. and E. Tsingou (eds). 2013. Great Expectations, Slow Transformations:

Incremental change in post-crisis regulation. Colchester: ECPR Press.

Muegge, D. 2013. 'Resilient Neoliberalism in European financial regulation'. In V. A.

Schmidt and M. Thatcher (eds), Resilient Liberalism in Europe's Political Economy.

Cambridge: Cambridge University Press, pp. 201-225.

Reay, M. 2012. The Flexible Unity of Economics. American Journal of Sociology, 118:1, p. 45-87

Roberts, M. E., Stewart, B. M., Tingley, D., Lucas, C., Leder-Luis, J., Gadarian, S. K., and Rand, D. G. 2014. Structural Topic Models for Open-Ended Survey Responses. American Journal of Political Science, 58(4), 1064-1082.

Steyvers, M., \& Griffiths, T. 2007. Probabilistic topic models. Handbook of latent semantic analysis, 427(7), 424-440.

Tarullo, D.K. 2014. Liquidity Regulation. Speech given at the Clearing House 2014 Annual Conference New York 
Thiemann, M., Aldegwy, M. S., \& Ibrocevic, E. 2017. Understanding the shift from micro to macroprudential thinking: a discursive network analysis. Cambridge Journal of Economics https://doi.org/10.1093/cje/bex056

Thiemann, M., Birk, M. and J. Friedrich. 2018. Much ado about nothing- Macro-prudential ideas and the post-crisis regulation of shadow banking. Koelner Zeitschrift fuer Soziologie und Sozialpsychologie forthcoming.

Tucker, P. 2016. The Design and Governance of Financial Stability Regimes: A Common Resource Problem That Challenges Technical Know-How, Democratic Accountability and International Coordination. CIGI Essays on International Finance, 3. https://www.cigionline.org/sites/default/files/financial_essay_vol.3_web.pdf

Tucker, P. 2014. Regulatory reform, stability and Central Banking. Brookings Institution. https://www.brookings.edu/wp-content/uploads/2016/06/16-regulatory-reform-stabilitycentral-banking-tucker.pdf

Underhill, G. R. 2015. The emerging post-crisis financial architecture: The path-dependency of ideational adverse selection. The British Journal of Politics and International Relations, 17(3), 461-493.

Underhill, G. 2015. 'The Emerging Post-Crisis Financial Architecture: The Path-Dependency of Ideational Adverse Selection'. British Journal of Politics and International

Relations, 17, 3, pp. 461-493. 


\section{Appendix A: Topics found in each subsample}

\begin{tabular}{|c|c|c|c|c|c|c|c|c|c|c|}
\hline Networks & $\begin{array}{l}\text { netwo } \\
\text { rk }\end{array}$ & node & $\begin{array}{l}\text { degr } \\
\text { e }\end{array}$ & connect & link & $\begin{array}{l}\text { centr } \\
\text { al }\end{array}$ & structur & $\begin{array}{l}\text { numbe } \\
r\end{array}$ & core & graph \\
\hline FX (esp. developing economies) & $\begin{array}{l}\text { countr } \\
\mathrm{i}\end{array}$ & $\begin{array}{l}\text { curren } \\
\text { c }\end{array}$ & rate & foreign & growth & $\begin{array}{l}\text { secto } \\
r\end{array}$ & intern & gdp & $\begin{array}{l}\text { develo } \\
\mathrm{p}\end{array}$ & $\begin{array}{l}\text { exchan } \\
\mathrm{g}\end{array}$ \\
\hline Measuring systemic risk & $\begin{array}{l}\text { syste } \\
\mathrm{m}\end{array}$ & risk & insur & financi & institut & $\begin{array}{l}\text { meas } \\
\text { ur }\end{array}$ & bank & sector & $\begin{array}{l}\text { contrib } \\
\text { ut }\end{array}$ & $\begin{array}{l}\text { exposu } \\
r\end{array}$ \\
\hline $\begin{array}{l}\text { Bank deposits \& their } \\
\text { insurance }\end{array}$ & bank & $\begin{array}{l}\text { deposi } \\
\mathrm{t}\end{array}$ & $\begin{array}{l}\text { syste } \\
\mathrm{m}\end{array}$ & insur & market & liquid & asset & Ioan & failur & $\begin{array}{l}\text { deposit } \\
\text { or }\end{array}$ \\
\hline Mortgage securitisation & $\begin{array}{l}\text { marke } \\
\mathrm{t}\end{array}$ & $\begin{array}{l}\text { financ } \\
\mathrm{i}\end{array}$ & secur & mortgag & feder & $\begin{array}{l}\text { reser } \\
\mathrm{v}\end{array}$ & asset & $\begin{array}{l}\text { compa } \\
\mathrm{ni}\end{array}$ & fund & loan \\
\hline Regulation & financi & regul & $\begin{array}{l}\text { syste } \\
\mathrm{m}\end{array}$ & risk & institut & $\begin{array}{l}\text { inter } \\
\mathrm{n}\end{array}$ & market & $\begin{array}{l}\text { regulat } \\
\text { ori }\end{array}$ & stabil & bank \\
\hline $\begin{array}{l}\text { Asset markets (esp. stock } \\
\text { market) }\end{array}$ & $\begin{array}{l}\text { marke } \\
\mathrm{t}\end{array}$ & model & time & data & financi & indic & correl & volatil & stock & period \\
\hline Risk estimation \& modelling & risk & $\begin{array}{l}\text { distrib } \\
\text { ut }\end{array}$ & estim & model & depend & tail & condit & measur & return & valu \\
\hline Bank funding & capit & bank & risk & equiti & debt & $\begin{array}{l}\text { requi } \\
r\end{array}$ & asset & regul & ratio & cost \\
\hline Hedge funds & fund & risk & $\begin{array}{l}\text { mark } \\
\text { et }\end{array}$ & hedg & asset & $\begin{array}{l}\text { retur } \\
\mathrm{n}\end{array}$ & investor & $\begin{array}{l}\text { portfoli } \\
\text { o }\end{array}$ & price & leverag \\
\hline Payment \& settlement systems & $\begin{array}{l}\text { payme } \\
\text { nt }\end{array}$ & bank & $\begin{array}{l}\text { syste } \\
\mathrm{m}\end{array}$ & secur & market & liquid & $\begin{array}{l}\text { settlem } \\
\text { ent }\end{array}$ & repo & $\begin{array}{l}\text { transac } \\
\mathrm{t}\end{array}$ & central \\
\hline Sovereign risk & bank & $\begin{array}{l}\text { countr } \\
\mathrm{i}\end{array}$ & risk & $\begin{array}{l}\text { sovereig } \\
\mathrm{n}\end{array}$ & stress & $\begin{array}{l}\text { sprea } \\
\text { d }\end{array}$ & cds & crisi & $\begin{array}{l}\text { europe } \\
\text { an }\end{array}$ & euro \\
\hline Interbank contagion & bank & $\begin{array}{l}\text { syste } \\
\mathrm{m}\end{array}$ & $\begin{array}{l}\text { defa } \\
\text { ult }\end{array}$ & $\begin{array}{l}\text { contagio } \\
\mathrm{n}\end{array}$ & interbank & asset & model & risk & shock & loss \\
\hline Equilibrium agent models & model & risk & $\begin{array}{l}\text { agen } \\
\mathrm{t}\end{array}$ & $\begin{array}{l}\text { equilibri } \\
\text { um }\end{array}$ & asset & $\begin{array}{l}\text { opti } \\
\mathrm{m}\end{array}$ & price & liquid & invest & follow \\
\hline financial stability & financi & rate & polici & crisi & system & $\begin{array}{l}\text { mark } \\
\text { et }\end{array}$ & price & $\begin{array}{l}\text { monet } \\
\text { ari }\end{array}$ & credit & $\begin{array}{l}\text { econo } \\
\mathrm{m}\end{array}$ \\
\hline $\begin{array}{l}\text { Panel studies, estimations \& } \\
\text { regressions }\end{array}$ & bank & $\begin{array}{l}\text { variab } \\
\text { I }\end{array}$ & tabl & result & return & effect & sampl & estim & regress & risk \\
\hline Derivatives \& counterparty risk & $\begin{array}{l}\text { marke } \\
\mathrm{t}\end{array}$ & trade & deriv & risk & $\begin{array}{l}\text { counterp } \\
\text { arti }\end{array}$ & $\begin{array}{l}\text { defau } \\
\text { It }\end{array}$ & clear & $\begin{array}{l}\text { contrac } \\
t\end{array}$ & cds & collater \\
\hline
\end{tabular}

Table 1: Top 10 most probable words for every topic in the SR sample

\begin{tabular}{|c|c|c|c|c|c|c|c|c|c|c|}
\hline Networks & node & $\begin{array}{l}\text { networ } \\
\mathrm{k}\end{array}$ & topolog & edg & peripheri & $\begin{array}{l}\text { connec } \\
\mathrm{t}\end{array}$ & layer & $\begin{array}{l}\text { neighb } \\
\text { or }\end{array}$ & modul & graph \\
\hline Garbage topic & signi & nancial & rst & cient & cant & cation & $\begin{array}{l}\text { divers } \\
\mathrm{i}\end{array}$ & ned & rms & bene \\
\hline $\begin{array}{l}\text { FX (esp. developing } \\
\text { economies) }\end{array}$ & currenc & export & latin & czech & foreign & gdp & $\begin{array}{l}\text { count } \\
\text { ri }\end{array}$ & asia & domest & growth \\
\hline Measuring systemic risk & reinsur & insur & covar & life & mes & srisk & sifi & $\begin{array}{l}\text { contri } \\
\text { but }\end{array}$ & system & sib \\
\hline $\begin{array}{l}\text { Bank deposits \& their } \\
\text { insurance }\end{array}$ & deposit & $\begin{array}{l}\text { deposit } \\
\text { or }\end{array}$ & bank & fail & guarante & $\begin{array}{l}\text { withdr } \\
\text { aw }\end{array}$ & failur & $\begin{array}{l}\text { compe } \\
\text { tit }\end{array}$ & hazard & safeti \\
\hline Mortgage securitisation & mortgag & shadow & sponsor & feder & lehman & aig & fed & securit & $\begin{array}{l}\text { bankru } \\
\text { ptci }\end{array}$ & fdic \\
\hline Regulation & supervis & $\begin{array}{l}\text { supervi } \\
\text { sori }\end{array}$ & $\begin{array}{l}\text { supervi } \\
\text { sor }\end{array}$ & $\begin{array}{l}\begin{array}{l}\text { commi } \\
\text { tte }\end{array} \\
\end{array}$ & prudenti & $\begin{array}{l}\text { commi } \\
\text { ss }\end{array}$ & $\begin{array}{l}\text { jurisdi } \\
\text { ct }\end{array}$ & $\begin{array}{l}\text { resolu } \\
\mathrm{t}\end{array}$ & $\begin{array}{l}\text { regulat } \\
\text { ori }\end{array}$ & reform \\
\hline $\begin{array}{l}\text { Asset markets (esp. stock } \\
\text { market) }\end{array}$ & $\begin{array}{l}\text { econom } \\
\text { etr }\end{array}$ & forecast & jun & sep & dec & energi & seri & mar & oil & $\begin{array}{l}\text { entrop } \\
\mathrm{i}\end{array}$ \\
\hline Risk estimation \& modelling & copula & tail & quantil & var & multivari & $\begin{array}{l}\text { asympt } \\
\text { ot }\end{array}$ & $\begin{array}{l}\text { extre } \\
\mathrm{m}\end{array}$ & $\begin{array}{l}\text { gaussi } \\
\text { an }\end{array}$ & $\begin{array}{l}\text { distribu } \\
\mathrm{t}\end{array}$ & $\begin{array}{l}\text { depen } \\
\text { d }\end{array}$ \\
\hline Bank funding & capit & $\operatorname{tax}$ & $\begin{array}{l}\text { compen } \\
\mathrm{s}\end{array}$ & equiti & incent & debt & basel & requir & conting & bonus \\
\hline Hedge funds & hedg & fund & tranch & $\begin{array}{l}\text { invest } \\
\text { or }\end{array}$ & arbitrag & option & $\begin{array}{l}\text { levera } \\
\mathrm{g}\end{array}$ & $\begin{array}{l}\text { portfol } \\
\text { io }\end{array}$ & strategi & jump \\
\hline $\begin{array}{l}\text { Payment \& settlement } \\
\text { systems }\end{array}$ & $\begin{array}{l}\text { paymen } \\
\mathrm{t}\end{array}$ & repo & $\begin{array}{l}\text { settlem } \\
\text { ent }\end{array}$ & card & electron & settl & $\begin{array}{l}\text { intrad } \\
\text { ay }\end{array}$ & $\begin{array}{l}\text { transa } \\
\text { ct }\end{array}$ & particip & $\begin{array}{l}\text { overni } \\
\text { ght }\end{array}$ \\
\hline Sovereign risk & $\begin{array}{l}\text { sovereig } \\
\mathrm{n}\end{array}$ & greec & spain & euro & ireland & $\begin{array}{l}\text { eurozo } \\
\mathrm{n}\end{array}$ & itali & portug & stress & $\begin{array}{l}\text { germa } \\
\mathrm{ni}\end{array}$ \\
\hline
\end{tabular}




\begin{tabular}{|l|l|l|l|l|l|l|l|l|l|l|} 
Interbank contagion & $\begin{array}{l}\text { interban } \\
\mathrm{k}\end{array}$ & $\begin{array}{l}\text { contagi } \\
\text { on }\end{array}$ & simul & default & shock & liabil & $\begin{array}{l}\text { chann } \\
\text { el }\end{array}$ & $\begin{array}{l}\text { fractio } \\
\mathrm{n}\end{array}$ & $\begin{array}{l}\text { algorit } \\
\text { sheet }\end{array}$ \\
\hline Equilibrium agent models & $\begin{array}{l}\text { equilibri } \\
\text { um }\end{array}$ & optim & $\begin{array}{l}\text { proposi } \\
\mathrm{t}\end{array}$ & agent & util & $\begin{array}{l}\text { constra } \\
\text { int }\end{array}$ & proof & trader & welfar & lemma \\
\hline financial stability & cycl & bubbl & $\begin{array}{l}\text { moneta } \\
\text { ri }\end{array}$ & output & boom & gap & $\begin{array}{l}\text { macr } \\
\text { o }\end{array}$ & inflat & polici & imbal \\
\hline $\begin{array}{l}\text { Panel studies, estimations \& } \\
\text { regressions }\end{array}$ & regress & variabl & dummi & sampl & Itd & yes & $\begin{array}{l}\text { coeffi } \\
\text { ci }\end{array}$ & panel & tabl & beta \\
\hline $\begin{array}{l}\text { Derivatives \& counterparty } \\
\text { risk }\end{array}$ & ccp & otc & clear & deriv & $\begin{array}{l}\text { counterp } \\
\text { arti }\end{array}$ & ccps & $\begin{array}{l}\text { deale } \\
\text { r }\end{array}$ & swap & trade & $\begin{array}{l}\text { contra } \\
\text { ct }\end{array}$ \\
\hline
\end{tabular}

Table 2: Top 10 most exclusive words for every topic in the SR sample

\begin{tabular}{|c|c|c|c|c|c|c|c|c|c|c|}
\hline Historical accounts of central banking/macroP & bank & market & financi & central & crisi & $\begin{array}{l}\text { gover } \\
\mathrm{n}\end{array}$ & $\begin{array}{l}\text { reser } \\
\mathrm{v}\end{array}$ & feder & $\begin{array}{l}\text { syste } \\
\mathrm{m}\end{array}$ & regul \\
\hline Monetary policy and financial stability & polici & $\begin{array}{l}\text { monet } \\
\text { ari }\end{array}$ & financi & central & stabil & bank & inflat & rate & price & $\begin{array}{l}\text { macropru } \\
\text { denti }\end{array}$ \\
\hline Political Economy & financi & system & $\begin{array}{l}\text { macropru } \\
\text { denti }\end{array}$ & institut & regul & polici & $\begin{array}{l}\text { mark } \\
\text { et }\end{array}$ & $\begin{array}{l}\text { econ } \\
\text { om }\end{array}$ & $\begin{array}{l}\text { proc } \\
\text { ess }\end{array}$ & network \\
\hline LTV & loan & credit & Itv & $\begin{array}{l}\text { macropru } \\
\text { denti }\end{array}$ & polici & $\begin{array}{l}\text { mortg } \\
\text { ag }\end{array}$ & hous & ratio & $\begin{array}{l}\text { meas } \\
\text { ur }\end{array}$ & effect \\
\hline $\begin{array}{l}\text { Growth and Macroeconomic development in } \\
\text { Asia and Latin America }\end{array}$ & $\begin{array}{l}\text { percen } \\
\mathrm{t}\end{array}$ & countri & region & develop & $\begin{array}{l}\text { econ } \\
\text { omi }\end{array}$ & fiscal & trade & $\begin{array}{l}\text { grow } \\
\text { th }\end{array}$ & $\begin{array}{l}\text { econ } \\
\text { om }\end{array}$ & latin \\
\hline Garbage/only produced by two documents & $\begin{array}{l}\text { constr } \\
\text { aint }\end{array}$ & price & model & $\begin{array}{l}\text { equilibriu } \\
\mathrm{m}\end{array}$ & $\begin{array}{l}\text { perio } \\
\mathrm{d}\end{array}$ & asset & debt & $\operatorname{tax}$ & polici & consumpt \\
\hline $\begin{array}{l}\text { Market measures like MVAR/GARCH/Business } \\
\text { cycle }\end{array}$ & model & variabl & estim & shock & price & data & time & index & $\begin{array}{l}\text { resul } \\
\mathrm{t}\end{array}$ & rate \\
\hline $\begin{array}{l}\text { Macorprudential Tools and Monetary policy in } \\
\text { DSGE models/BC\# }\end{array}$ & polici & nancial & shock & model & rate & $\begin{array}{l}\text { mone } \\
\text { tari }\end{array}$ & capit & rule & $\begin{array}{l}\text { outp } \\
\text { ut }\end{array}$ & credit \\
\hline $\begin{array}{l}\text { Conventional Monetary policy tools (IT,Rserve } \\
\text { requirements) }\end{array}$ & rate & bank & reserv & exchang & $\begin{array}{l}\text { requi } \\
\mathrm{r}\end{array}$ & loan & credit & $\begin{array}{l}\text { incre } \\
\text { as }\end{array}$ & $\begin{array}{l}\text { perce } \\
\mathrm{nt}\end{array}$ & deposit \\
\hline Stress testing & stress & bank & risk & test & $\begin{array}{l}\text { finan } \\
\mathrm{ci}\end{array}$ & loss & $\begin{array}{l}\text { scena } \\
\text { rio }\end{array}$ & $\begin{array}{l}\text { secto } \\
r\end{array}$ & $\begin{array}{l}\text { syste } \\
\mathrm{m}\end{array}$ & model \\
\hline MacroP and the housing markets & hous & $\begin{array}{l}\text { house } \\
\text { hold }\end{array}$ & price & debt & rate & $\begin{array}{l}\text { mortg } \\
\text { ag }\end{array}$ & $\begin{array}{l}\text { inco } \\
\mathrm{m}\end{array}$ & $\begin{array}{l}\text { incre } \\
\text { as }\end{array}$ & $\operatorname{tax}$ & market \\
\hline Leverage bubbles & financi & credit & asset & leverag & cycl & risk & price & $\begin{array}{l}\text { boo } \\
\mathrm{m}\end{array}$ & bank & capit \\
\hline Early warning indicators & $\begin{array}{l}\text { countr } \\
\mathrm{i}\end{array}$ & credit & crisi & indic & $\begin{array}{l}\text { finan } \\
\mathrm{ci}\end{array}$ & $\operatorname{gdp}$ & $\begin{array}{l}\text { grow } \\
\text { th }\end{array}$ & bank & $\begin{array}{l}\text { varia } \\
\text { bl }\end{array}$ & ratio \\
\hline MacroP supiversory setup post crises & bank & financi & risk & system & capit & stabil & regul & $\begin{array}{l}\text { instit } \\
\text { ut }\end{array}$ & $\begin{array}{l}\text { requi } \\
\mathrm{r}\end{array}$ & prudenti \\
\hline Capital regulation as a macroP tool & bank & capit & risk & asset & liquid & cost & regul & $\begin{array}{l}\text { requi } \\
\mathrm{r}\end{array}$ & $\begin{array}{l}\text { mod } \\
\text { el }\end{array}$ & deposit \\
\hline Banking market structure & bank & capit & loan & lend & ratio & effect & asset & total & firm & result \\
\hline Capital flows and macroP regulation & capit & countri & foreign & flow & $\begin{array}{l}\text { curre } \\
\text { nc }\end{array}$ & polici & $\begin{array}{l}\text { dome } \\
\text { st }\end{array}$ & $\begin{array}{l}\text { exch } \\
\text { ang }\end{array}$ & $\begin{array}{l}\text { meas } \\
\text { ur }\end{array}$ & intern \\
\hline $\begin{array}{l}\text { Asset Price bubbles based on information } \\
\text { asym. }\end{array}$ & bubbl & model & firm & price & $\begin{array}{l}\text { mark } \\
\text { et }\end{array}$ & $\begin{array}{l}\text { infor } \\
\mathrm{m}\end{array}$ & $\begin{array}{l}\text { prod } \\
\text { uct }\end{array}$ & valu & $\begin{array}{l}\text { expe } \\
\mathrm{ct}\end{array}$ & invest \\
\hline Shadow Banking/Hedge funds & $\begin{array}{l}\text { marke } \\
t\end{array}$ & liquid & fund & asset & risk & $\begin{array}{l}\text { financ } \\
\mathrm{i}\end{array}$ & bank & $\begin{array}{l}\text { inves } \\
t\end{array}$ & term & bond \\
\hline
\end{tabular}

Table 3: Top 10 most probable words for every topic in the MP sample

\begin{tabular}{|c|c|c|c|c|c|c|c|c|c|c|}
\hline $\begin{array}{l}\text { Historical } \\
\text { accounts of } \\
\text { central } \\
\text { banking/macroP }\end{array}$ & $\begin{array}{l}\text { govern } \\
\text { or }\end{array}$ & feder & england & treasuri & war & congress & bill & presid & act & offici \\
\hline $\begin{array}{l}\text { Monetary policy } \\
\text { and financial } \\
\text { stability }\end{array}$ & $\begin{array}{l}\text { monet } \\
\text { ari }\end{array}$ & inflat & polici & target & stabil & imbal & object & central & transmiss & $\begin{array}{l}\text { manda } \\
\mathrm{t}\end{array}$ \\
\hline Political Economy & $\begin{array}{l}\text { networ } \\
\mathrm{k}\end{array}$ & $\begin{array}{l}\text { comple } \\
x\end{array}$ & polit & oversight & collect & actor & agenc & process & connect & organ \\
\hline LTV & Itv & cap & kong & mortgag & dti & hong & tighten & loan & $\begin{array}{l}\text { macroprud } \\
\text { enti }\end{array}$ & $\begin{array}{l}\text { proper } \\
\text { ti }\end{array}$ \\
\hline $\begin{array}{l}\text { Growth and } \\
\text { Macroeconomic } \\
\text { development in } \\
\text { Asia and Latin } \\
\text { America }\end{array}$ & latin & america & region & china & asia & fiscal & export & commod & usa & oil \\
\hline
\end{tabular}




\begin{tabular}{|c|c|c|c|c|c|c|c|c|c|c|}
\hline $\begin{array}{l}\text { Garbage/only } \\
\text { produced by two } \\
\text { documents }\end{array}$ & $\begin{array}{l}\text { constra } \\
\text { int }\end{array}$ & bind & $\begin{array}{l}\text { equilibri } \\
\text { um }\end{array}$ & labor & collater & trader & $\begin{array}{l}\text { constrai } \\
\mathrm{n}\end{array}$ & planner & land & agent \\
\hline $\begin{array}{l}\text { Market measures } \\
\text { like } \\
\text { MVAR/GARCH/B } \\
\text { usiness cycle }\end{array}$ & $\begin{array}{l}\text { forecas } \\
t\end{array}$ & var & estim & error & varianc & index & compon & vector & seri & lag \\
\hline $\begin{array}{l}\text { Macorprudential } \\
\text { Tools and } \\
\text { Monetary policy } \\
\text { in DSGE } \\
\text { models/BC\# }\end{array}$ & nancial & ect & ation & rst & erent & rms & cient & $\begin{array}{l}\text { entrepren } \\
\text { eur }\end{array}$ & steadi & nanc \\
\hline $\begin{array}{l}\text { Conventional } \\
\text { Monetary policy } \\
\text { tools (IT,Rserve } \\
\text { requirements) }\end{array}$ & $\begin{array}{l}\text { exchan } \\
\mathrm{g}\end{array}$ & reserv & rate & dev & deposit & inflat & nomin & depreci & jan & export \\
\hline Stress testing & stress & $\begin{array}{l}\text { scenari } \\
\text { o }\end{array}$ & test & loss & provis & default & exposur & portfolio & solvenc & $\begin{array}{l}\text { contagi } \\
\text { on }\end{array}$ \\
\hline $\begin{array}{l}\text { MacroP and the } \\
\text { housing markets }\end{array}$ & hous & rent & $\begin{array}{l}\text { househ } \\
\text { old }\end{array}$ & oecd & wealth & mortgag & age & incom & amort & home \\
\hline Leverage bubbles & leverag & cycl & cyclic & boom & recess & procycl & $\begin{array}{l}\text { counter } \\
\text { cycl }\end{array}$ & bust & downturn & securit \\
\hline $\begin{array}{l}\text { Early warning } \\
\text { indicators }\end{array}$ & indic & warn & gdp & countri & crise & czech & $\begin{array}{l}\text { threshol } \\
\text { d }\end{array}$ & gap & signal & republ \\
\hline $\begin{array}{l}\text { MacroP } \\
\text { supiversory setup } \\
\text { post crises }\end{array}$ & $\begin{array}{l}\text { supervi } \\
\mathrm{s}\end{array}$ & $\begin{array}{l}\text { supervi } \\
\text { sori }\end{array}$ & basel & $\begin{array}{l}\text { supervis } \\
\text { or }\end{array}$ & $\begin{array}{l}\text { recomm } \\
\text { end }\end{array}$ & $\begin{array}{l}\text { europea } \\
n\end{array}$ & $\begin{array}{l}\text { committ } \\
\mathrm{e}\end{array}$ & resolut & prudenti & ensur \\
\hline $\begin{array}{l}\text { Capital regulation } \\
\text { as a macroP tool }\end{array}$ & $\begin{array}{l}\text { wholes } \\
\text { al }\end{array}$ & banker & riski & $\begin{array}{l}\text { intermed } \\
\text { iari }\end{array}$ & retail & fire & return & intermedi & outsid & incent \\
\hline $\begin{array}{l}\text { Banking market } \\
\text { structure }\end{array}$ & yes & lend & total & column & regress & $\begin{array}{l}\text { relations } \\
\text { hip }\end{array}$ & branch & firm & profit & sampl \\
\hline $\begin{array}{l}\text { Capital flows and } \\
\text { macroP } \\
\text { regulation }\end{array}$ & flow & inflow & foreign & currenc & border & eme & domest & global & local & $\begin{array}{l}\text { exchan } \\
\mathrm{g}\end{array}$ \\
\hline $\begin{array}{l}\text { Asset Price } \\
\text { bubbles based on } \\
\text { information } \\
\text { asym. }\end{array}$ & bubbl & belief & ration & learn & $\begin{array}{l}\text { fundame } \\
\mathrm{nt}\end{array}$ & $\begin{array}{l}\text { uncertai } \\
\text { nti }\end{array}$ & sell & burst & screen & firm \\
\hline $\begin{array}{l}\text { Shadow } \\
\text { Banking/Hedge } \\
\text { funds }\end{array}$ & hedg & cash & billion & secur & compani & insur & liquid & swap & jan & fund \\
\hline
\end{tabular}

Table 4: Top 10 most exclusive words for every topic in the MP sample

\begin{tabular}{|c|c|c|c|c|c|c|c|c|c|c|}
\hline Macroprudential concepts/tools & financ & polici & system & risk & $\begin{array}{l}\text { macropruden } \\
\mathrm{ti}\end{array}$ & stabil & bank & institut & $\begin{array}{l}\text { moneta } \\
\text { ri }\end{array}$ & market \\
\hline $\begin{array}{l}\text { Evaluation of macroP tools/Cross country } \\
\text { comparison }\end{array}$ & polici & bank & credit & loan & capit & $\begin{array}{l}\text { macropruden } \\
\mathrm{ti}\end{array}$ & rate & ratio & requir & $\begin{array}{l}\text { percen } \\
t\end{array}$ \\
\hline Macroprudential regulatory system & bank & financi & system & risk & market & regul & institu & crisi & liquid & $\begin{array}{l}\text { supervi } \\
\text { s }\end{array}$ \\
\hline Attributing SR to institutions & $\begin{array}{l}\text { syste } \\
\text { m }\end{array}$ & risk & bank & financi & measur & regul & capit & linstitut & econom & crisi \\
\hline Indicators for counter-cycl- regulation & bank & i & credit & rate & sector & financi & indic & growth & gdp & loan \\
\hline $\begin{array}{l}\text { Early warning systems/Forward looking SR } \\
\text { measures }\end{array}$ & risk & model & financi & $\begin{array}{l}\text { marke } \\
\mathrm{t}\end{array}$ & system & fund & data & stress & estim & time \\
\hline
\end{tabular}




\begin{tabular}{|c|c|c|c|c|c|c|c|c|c|c|}
\hline SR in the banking system & bank & loan & risk & $\begin{array}{l}\text { variab } \\
1\end{array}$ & asset & capit & $\begin{array}{l}\text { deposi } \\
\mathrm{t}\end{array}$ & result & total & effect \\
\hline Network/Contagion & bank & $\begin{array}{l}\text { syste } \\
\text { m }\end{array}$ & $\begin{array}{l}\text { networ } \\
k\end{array}$ & risk & model & asset & liquid & $\begin{array}{l}\text { interban } \\
k\end{array}$ & default & capit \\
\hline Agent-Based-Modeling & bank & asset & price & regul & polici & invest & $\begin{array}{l}\text { levera } \\
\mathrm{g}\end{array}$ & model & cost & market \\
\hline
\end{tabular}

Table 5: Top 10 most probable words for every topic in the overlap sample

\begin{tabular}{|c|c|c|c|c|c|c|c|c|c|c|}
\hline Macroprudential concepts/tools & tool & $\begin{array}{l}\text { macroprude } \\
\text { nti }\end{array}$ & macro & bis & stabil & $\begin{array}{l}\text { pruden } \\
\text { ti }\end{array}$ & $\begin{array}{l}\text { microprude } \\
\text { nti }\end{array}$ & object & polici & cycl \\
\hline $\begin{array}{l}\text { Evaluation of macroP tools/Cross country } \\
\text { comparison }\end{array}$ & Itv & percent & hous & $\begin{array}{l}\text { mortga } \\
\text { g }\end{array}$ & $\begin{array}{l}\text { proper } \\
\mathrm{ti}\end{array}$ & reserv & tighten & limit & cap & instrumen \\
\hline Macroprudential regulatory system & resolut & supervisori & supervis & repo & reform & law & supervisor & legal & manag & act \\
\hline Attributing SR to institutions & tail & reliabl & acharya & system & $\begin{array}{l}\text { shortf } \\
\text { al }\end{array}$ & covar & var & inc & regul & $\begin{array}{l}\text { brunnerm } \\
\text { ei }\end{array}$ \\
\hline Indicators for counter-cycl- regulation & gap & euro & $\begin{array}{l}\text { househo } \\
\text { Id }\end{array}$ & foreign & $g d p$ & trend & percentag & curren & save & chart \\
\hline $\begin{array}{l}\text { Early warning systems/Forward looking SR } \\
\text { measures }\end{array}$ & stress & data & estim & $\begin{array}{l}\text { compo } \\
\text { n }\end{array}$ & volatil & $\begin{array}{l}\text { forecas } \\
t\end{array}$ & industri & signal & predict & lag \\
\hline SR in the banking system & securit & regress & variabl & dummi & coeffic & column & signific & deposi & $\begin{array}{l}\text { withdra } \\
\text { w }\end{array}$ & cross \\
\hline Network/Contagion & network & interbank & $\begin{array}{l}\text { contagio } \\
n\end{array}$ & default & $\begin{array}{l}\text { conne } \\
\text { ct }\end{array}$ & $\begin{array}{l}\text { scenari } \\
0\end{array}$ & nancial & expos & simul & ect \\
\hline Agent-Based-Modeling & $\begin{array}{l}\text { equilibriu } \\
\mathrm{m}\end{array}$ & constraint & welfar & banker & optim & agent & shadow & fire & sale & investor \\
\hline
\end{tabular}

Table 6: Top 10 most exclusive words for every topic in the overlap sample 


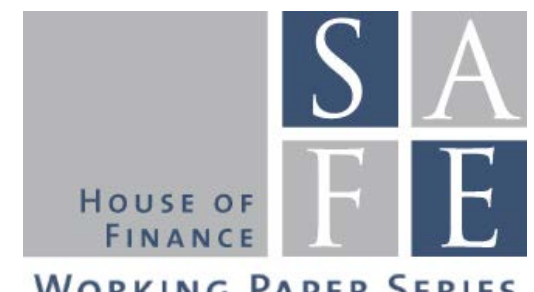

WORKING PAPER SERIES

\section{Recent Issues}

No. 213 Klaus Gugler, Michael Weichselbaumer, Christine Zulehner

No. 212 Henning Hesse

No. 211 Thomas Mosk

No. 210 Darien Huang, Christian Schlag, Ivan Shaliastovich, Julian Thimme

No. 209 Eren Gürer, Alfons J.

Weichenrieder

No. 208 Roberto Casarin, Michele Costola, Erdem Yenerdag

No. 207 Claes Bäckman, Tobin Hanspal

No. 206 Loriana Pelizzon, Anjan Thakor, Calebe de Roure

No. 205 Horst Entorf, Jia Hou

No. 204 Loriana Pelizzon, Matteo Sottocornola

No. 203 Florian Hett, Felix Schmidt

No. 202 Tobias H. Tröger

No. 201 Dirk Krueger, Alexander Ludwig

No. 200 Nils Grevenbrock, Max Groneck, Alexander Ludwig, Alexander Zimper

No. 199 Tobias H. Tröger
Effects of Government Spending on Employment: Evidence from Winners and Runners-up in Procurement Auctions

Incentive Effects from Write-down CoCo Bonds: An Empirical Analysis

Bargaining with a Bank

Volatility-of-Volatility Risk

Pro-rich Inflation in Europe: Implications for the Measurement of Inequality

Financial Bridges and Network Communities

The Geography of Alternative Work

P2P Lending versus Banks: Cream Skimming or Bottom Fishing?

Financial Education for the Disadvantaged? A Review

The Impact of Monetary Policy Interventions on the Insurance Industry

Pushing Through or Slacking Off? Heterogeneity in the Reaction to Rank Feedback

Germany's Reluctance to Regulate Related Party Transactions

Optimal Taxes in the OLG Model with Uninsurable Idiosyncratic Income Risk

Cognition, Optimism and the Formation of Age-Dependent Survival Beliefs

Regulation of Crowdfunding in Germany 